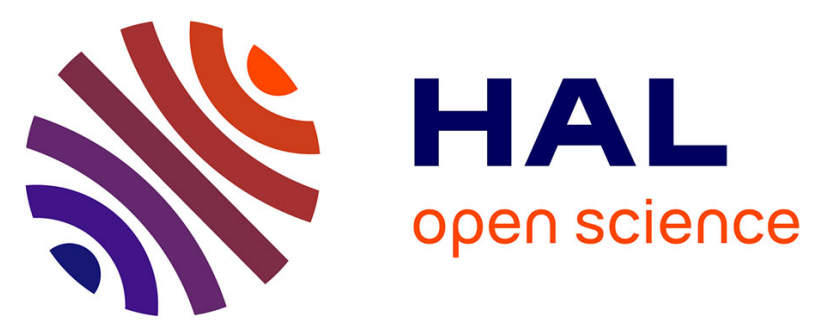

\title{
Gas-Phase Interactions between Lead(II) Ions and Cytosine: Tandem Mass Spectrometry and Infrared Multiple-Photon Dissociation Spectroscopy Study
}

Jean-Yves Salpin, Violette Haldys, Sébastien Guillaumont, Jeanine Tortajada, Marcela Hurtado, Al Mokhtar Lamsabhi

\section{- To cite this version:}

Jean-Yves Salpin, Violette Haldys, Sébastien Guillaumont, Jeanine Tortajada, Marcela Hurtado, et al.. Gas-Phase Interactions between Lead(II) Ions and Cytosine: Tandem Mass Spectrometry and Infrared Multiple-Photon Dissociation Spectroscopy Study. ChemPhysChem, 2014, 15 (14), pp.29592971. 10.1002/cphc.201402369 . hal-01221270

\author{
HAL Id: hal-01221270 \\ https://hal.science/hal-01221270
}

Submitted on 8 Oct 2018

HAL is a multi-disciplinary open access archive for the deposit and dissemination of scientific research documents, whether they are published or not. The documents may come from teaching and research institutions in France or abroad, or from public or private research centers.
L'archive ouverte pluridisciplinaire HAL, est destinée au dépôt et à la diffusion de documents scientifiques de niveau recherche, publiés ou non, émanant des établissements d'enseignement et de recherche français ou étrangers, des laboratoires publics ou privés. 


\section{Gas-phase interactions between Lead(II) ions and Cytosine: Tandem Mass}

\section{Spectrometry and Infrared Multiple-Photon Dissociation Spectroscopy Study}

Jean-Yves Salpin ${ }^{* 1,2}$, Violette Haldys ${ }^{1,2}$, Sébastien Guillaumont ${ }^{1,2}$, Jeanine Tortajada ${ }^{1,2}$, Marcela Hurtado ${ }^{3}$ and Al Mokhtar Lamsabhi*3

1. Université d'Evry Val d'Essonne, Laboratoire Analyse et Environnement pour la Biologie et l'Environnement, Bâtiment Maupertuis, Boulevard François Mitterrand, 91025 Evry Cedex, France

2. CNRS - UMR 8587

3. Departamento de Química, C-9. Universidad Autónoma de Madrid. Cantoblanco, 28049 Madrid, Spain

Corresponding author: Jean-Yves Salpin

Tel: 33169477644 Fax: 33169477655

e-mail : Jean-Yves.Salpin@ univ-evry.fr

Al Mokhtar Lamsabhi

Tel: 34914975017 Fax: 34914975238

e-mail : mokhtar.lamsabhi@uam.es

Number of pages (including Tables, Figures, legends and schemes) : 37

Keywords: Lead cationization, cytosine, tandem mass spectrometry, IRMPD spectroscopy, DFT calculations. 


\begin{abstract}
Gas-phase interactions between $\mathrm{Pb}^{2+}$ ions and cytosine $(\mathrm{C})$ have been studied by combining tandem mass spectrometry, infrared multiple photon dissociation (IRMPD) spectroscopy and density functional theory (DFT) calculations. Both singly and doubly-charged complexes were generated by electrospray. The $[\mathrm{Pb}(\mathrm{C})-\mathrm{H}]^{+}$complex has been extensively studied and this study shows that two structures, involving the interaction of the metal with the deprotonated canonical keto-amino tautomer of cytosine, are generated in the gas phase, the prominent structure being a bidentate form involving both $\mathrm{N} 1$ and $\mathrm{O} 2$ electronegative centers. The DFT study also points out a significant charge transfer from the nucleobase to the low-lying $\mathrm{p}$ orbitals of the metal, and a strong polarization of the base upon complexation. The various potential energy surfaces explored to account for the fragmentation observed are consistent with the high abundance of the $\left[\mathrm{PbNH}_{2}\right]^{+}$fragment ion.
\end{abstract}

\title{
Keywords
}

Gas-phase interactions; $\mathrm{Pb}^{2+}$ ions; cytosine; MS/MS spectra; IRMPD spectroscopy 


\section{Introduction:}

The implication of metals in many biological processes is the most important clue that motivated many scientists to explore their reactivity towards a quite vast range of molecules. Metals are generally taken as essential for human health since they form an integral part of enzymes involved in many metabolic or biochemical processes. However, an increase in ingested amounts may cause serious damages in the cell. It has been shown for instance that calcium $^{[1]}$ in spite of its biological importance, can become toxic if its ingestion exceeds some limits. The problem becomes even more serious when metals with known toxicity are ingested even in trace quantities. Nowadays, due to the contamination of many media arising from anthropogenic activities, small amounts of toxic metals released may be found within aliments, even under drastic health governmental controls.

Metals can interact with the DNA or the RNA components in the cell, leading to genetic alterations. For example, copper is one of the metals with capacity to interact with nucleic $\operatorname{acids}^{[2-4]}$, and shows a rather high affinity for DNA as compared to other divalent metals. ${ }^{[5,6]}$ Lead is another metal whose toxicity is well known and its health damages are well established. Different reports have shown that the toxicity of this metal is partly due to its interaction with nucleic acids. ${ }^{[7-9]}$

Recently, we have studied by means of MS/MS experiments and theoretical calculations the reactivity of thymine, uracil and its thio homologues towards lead. ${ }^{[10,11]}$ Besides the structural study of the complexes, our main interest was to explore the different pathways that could account for the fragmentation observed onto MS/MS spectra. It is worth noting that a particularly abundant fragment obtained for uracil/ $\mathrm{Pb}^{2+}$ and thymine/ $\mathrm{Pb}^{2+}$ systems is the 
$[\mathrm{Pb}, \mathrm{C}, \mathrm{O}, \mathrm{N}]^{+}$ion. Taking a look at the structure of these molecules, two positions ( 2 and 4 ; scheme 1) are possible for the interaction of lead before going ahead to the dissociation.

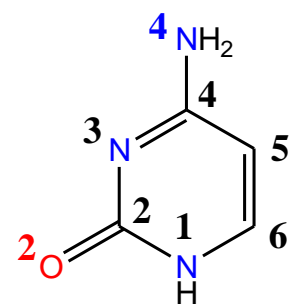

Cytosine

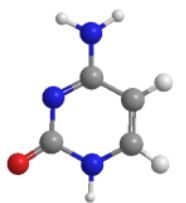

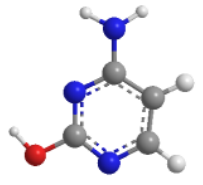

2a

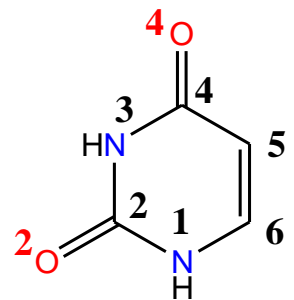

Uracil

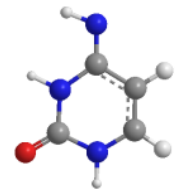

3a<smiles>Cc1c[nH]c(=O)[nH]c1=O</smiles>

Thymine

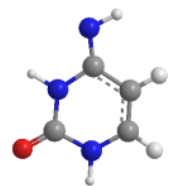

$3 b$

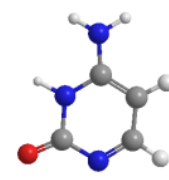

4

Scheme 1: structure of the three pyrimidine nucleobases (top) and list of the different tautomers of Cytosine considered during this work (bottom)

Reminding that these complexes are deprotonated prior to fragmentation, we have shown by labelling experiments, and by computing the main intermediates and transition states of the associated potential energy surface, a reasonable explanation of the processes involved. Actually, the formation of $[\mathrm{PbNCO}]^{+}$specifically involves both $\mathrm{O} 2$ and $\mathrm{N} 3$ atoms (scheme 1), and comes from the dissociation of an intermediate in which lead is bicoordinated to these two basic centers. This means that the carbonyl group in position 4 , although more basic ${ }^{[12-14]}$ does not directly participate in this process. It was concluded that even if the metal prefers the $\mathrm{O} 4$ position, the electronic and the structural changes entailed in the complexation are the ones responsible for fragmentation observed experimentally. The question that one should now address is what about the effect of changing a carbonyl group by an amino group in uracil? Will we obtain a similar dissociation scheme? What about the interaction patterns of the metal with the new species? To address these questions, we presently report the study of 
the interaction of cytosine towards $\mathrm{Pb}^{2+}$ since it is the result of replacing carbonyl in position 4 of uracil by an amino group. The main goal of this work is to highlight the interaction of lead with another nucleobase. In order to obtain a complete picture of the reactivity patterns of cytosine, this work has been done by combining MS/MS experiments, IRMPD spectroscopy, and the theoretical calculations.

\section{Methodology}

a) Mass spectrometry Electrospray mass spectra were recorded on an Applied Biosystems/MDS Sciex API2000 triple-quadrupole instrument fitted with a "turboionspray" ion source. Solutions of Lead nitrate/cytosine at various concentrations were prepared in Milli-Q water/methanol mixture $(50 / 50 \mathrm{v} / \mathrm{v})$, and were introduced in the source using direct infusion with a syringe pump, at a flow rate of $5 \mu \mathrm{l} / \mathrm{min}$. Ionization of the samples was achieved by applying a voltage of $4.0 \mathrm{kV}$ on the sprayer probe and by the use of a nebulizing gas (GAS1, air) surrounding the sprayer probe, intersected by a heated gas (GAS2, air) at an angle of approximately $90^{\circ}$. The operating pressure of GAS1 and GAS2 are adjusted to 2.1 bars, by means of an electronic board (pressure sensors), as a fraction of the air inlet pressure. The curtain gas $\left(\mathrm{N}_{2}\right)$, which prevents air or solvent from entering the analyzer region, was similarly adjusted to a value of 1.4 bars. The temperature of GAS2 was set at $100^{\circ} \mathrm{C}$.

MS/MS spectra were carried out by introducing nitrogen as collision gas in the second quadrupole at a total pressure of $3 \times 10^{-5} \mathrm{mbar}$, the background pressure being around $10^{-5}$ mbar as measured by the ion gauge located outside the collision cell. However, the pressure inside the collision cell is fact in the order of 10 mTorr. ${ }^{[15]}$ It is worth mentioning that, as discussed in previous papers, MS/MS spectra are very likely obtained under multiple-collision regime and this will increase the internal energy content of the precursor ion. ${ }^{[16,17]}$ MS/MS spectra were recorded at different collision energies 
ranging from 0 to $35 \mathrm{eV}$ in the laboratory frame (the kinetic energy of ions is given by the difference of potentials between the focusing quadrupole Q0 preceding Q1, and the collision cell Q2).

b) IRMPD spectroscopy. The present IRMPD spectroscopic investigation has been performed using an experimental platform based on modified Bruker Esquire 3000 quadrupole ion trap, which has been described in details previously. ${ }^{[18-20]}$

Tunable mid-infrared radiation is produced by the Free Electron Laser (FEL) of CLIO (Centre Laser Infrarouge d'Orsay). ${ }^{[21]}$ The FEL radiation is generated by a $10-50 \mathrm{MeV}$ electron linear accelerator and is delivered in $8 \mu$ s-long macropulses at a repetition rate of $25 \mathrm{~Hz}$, each containing few hundred micropulses (few picoseconds long). Typical macropulse energies are $40 \mathrm{~mJ}$. Ions were irradiated for $150 \mathrm{~ms}$ with the IR FEL radiation. Using a fixed electron energy, the energy of the emitted photons can be continuously scanned by adjusting the undulator gap. For the present study, the FEL was operated at $44 \mathrm{MeV}$ in order to optimize the laser power in the frequency region of interest (1000$2000 \mathrm{~cm}^{-1}$ ). The laser wavelength profile was monitored at each reading with a monochromator associated with a pyroelectric detector array (spiricon). The IR-FEL spectral width, which can be adjusted through a tuning of the optical cavity length, was found to be less than $0.5 \%$ of the central wavelength.

Multistage mass spectrometry was carried out using the standard Bruker Esquire Control (v5.2) software, and mass-selected ions were irradiated using the MS2 step where the excitation amplitude was set to 0 to avoid any CID-like process. Mass spectra were recorded after 10 accumulations, using the standard mass range $(\mathrm{m} / \mathrm{z}, 50-3000)$ and the normal scan resolution $(13000 \mathrm{Th} / \mathrm{s})$, the accumulation time being typically of $5 \mathrm{~ms}$. This sequence was repeated ten times for each photon energy.

Lead nitrate/cytosine solutions at $10^{-4} \mathrm{M}$ were prepared in Milli-Q water/methanol mixture (50/50 $\mathrm{v} / \mathrm{v}$ ) and were introduced in the source using direct infusion with a syringe pump. ESI conditions 
used were as follows: flow rate of $3 \mu \mathrm{l} / \mathrm{min}$, spray voltage $3500 \mathrm{~V}$ and a capillary temperature of 473 K.

c) Computational details. DFT calculations were carried out using B3LYP functional, as implemented in the Gaussian-03/-09 set of programs. ${ }^{[22]}$ B3LYP combines the non local correlation function of Lee, Yang and Parr, ${ }^{[23]}$ with the Becke's three-parameter non local hybrid exchange functional. ${ }^{[24]}$ The different structures were first optimized with the dp-polarized 6-31G(d,p) basis set for $\mathrm{C}, \mathrm{H}, \mathrm{N}$ and $\mathrm{O}$ atoms, without the constraint on a possible planarity. Harmonic vibrational frequencies were estimated at this level to classify stationary points as local minima or saddle points, and to estimate the zero-point vibrational energy (ZPVE) corrections. To determine the connectivity between each transition structure and its adjacent minima, we have used the intrinsic reaction coordinate (IRC) procedure. ${ }^{[25]}$ Finally, relative energies were determined using the extended basis set $6-311+\mathrm{G}(3 \mathrm{df}, 2 \mathrm{p})$.

Different effective core potentials have been proposed in the literature for $\mathrm{Pb}$. In the present study, we used the "Stuttgart" quasi-relativistic pseudo-potential developed by Küchle et al ${ }^{[26]}$. This particular ECP employs a $(4 s, 4 p, 1 d) /[2 s, 2 p, 1 d]$ basis set with a $(3,1)$ contraction scheme for $s$ and $p$ functions. Hence, this basis set can be used directly in conjunction with the standard 6-31G(d,p) Pople basis set of C, N, O and H, for geometry optimization.

To perform calculations at a higher level of theory, we developed ${ }^{[27]} 6-311+G(2 d f)$ and $6-311+G(3 d f)$ extended basis sets to be used in conjunction with a couple of pseudo-potentials. During this study, it turned out that B3LYP/Stuttgart approaches provide a good compromise between accuracy and computational cost in the calculation of binding energies. For simplicity in nomenclature, the basis sets used for $\mathrm{Pb}$ in conjunction with the 6-31G(d,p) and $6-311+G(3 d f, 2 p)$ for the remaining atoms, will now be referred to as $6-31 G(d, p)$ and $6-311+\mathrm{G}(3 \mathrm{df}, 2 \mathrm{p})$ basis sets, respectively. It is important to note that very recently a new theoretical 
assessment of lead containing compounds has been published, ${ }^{[28]}$ and B3LYP functional was found to predict reasonably well the experimental infrared data. This could be considered an additional argument of the level of theory chosen in the present work.

To give a picture of the distribution of charge within the different species, we have carried out a natural population analysis (NPA) at the B3LYP/6-31G(d,p) level by means of the NBO program for all the structures investigated. ${ }^{[29]}$ The bonding within the individual equilibrium structures was also analyzed by locating the bond critical points (BCPs) using atoms-in-molecules (AIM) theory, ${ }^{[30,31]}$ which is based on a topological analysis of the charge density. The electron density at the bcps is a good measure of the bond strength.

Throughout this paper total energies are expressed in hartree and relative energies in $\mathrm{kJ} / \mathrm{mol}$. Unless otherwise noted, the relative energies given hereafter are those obtained at a level equivalent to B3LYP/6-311+G(3df,2p)//B3LYP/6-31G(d,p)+ZPE. Detailed geometries of all the structures mentioned in this paper (neutral and deprotonated cytosine and $\mathrm{Pb}^{2+} /$ cytosine complexes) are available upon request.

Finally, note that mass to charge ratios mentioned throughout this paper refer to as peaks which include the most abundant lead isotope $\left({ }^{208} \mathrm{~Pb}\right)$. Nucleobases and lead nitrate were purchased from Aldrich and were used without further purification.

\section{Results-discussion}

Positive-ion electrospray spectra of $\mathrm{Pb}\left(\mathrm{NO}_{3}\right)_{2} /$ cytosine mixture. Positive-ion electrospray mass spectra were recorded at different values of declustering potential (DP), ranging from 0 to $200 \mathrm{~V}$. DP is defined as the difference of potentials between the orifice plate and the skimmer (grounded), and typically refers to as the "cone voltage" for other electrospray interfaces. A typical positive-ion electrospray spectra of a water/methanol equimolar mixture of lead nitrate and cytosine $\left(10^{-4} \mathrm{M}\right)$ recorded with a DP of $20 \mathrm{~V}$, is given in Figure 1a. 

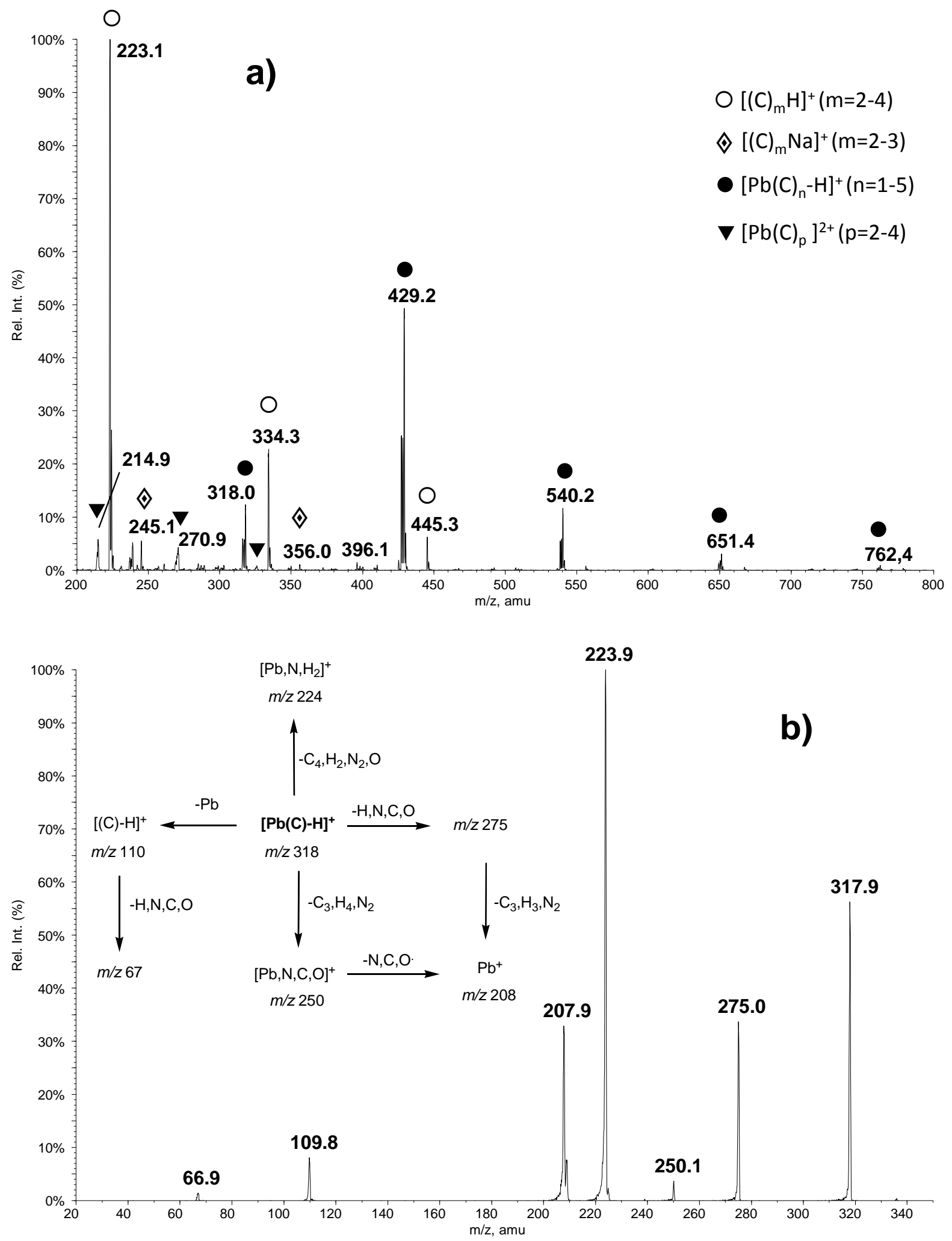

Figure 1: a) Positive-ion electrospray mass spectrum of an equimolar $\left(10^{-4} \mathrm{M}\right)$ mixture of $\mathrm{Pb}\left(\mathrm{NO}_{3}\right)_{2}$ /cytosine $\left(\mathrm{H}_{2} \mathrm{O} /\right.$ methanol $\left.50 / 50 \mathrm{v} / \mathrm{v}\right)$ recorded at $\mathrm{DP}=20 \mathrm{~V}$, and b) low-energy CID spectrum of $[\mathrm{Pb}(\mathrm{C})-\mathrm{H}]^{+}$ions recorded with a collision energy of $30 \mathrm{eV}$ (laboratory frame). 
As compared to the spectrum obtained with uracil or thymine, ${ }^{[10]}$ species corresponding to protonation of the nucleobase are much more intense and dominate the spectrum. This was expected since cytosine $(\mathrm{C})$ is sensibly more basic than uracil and thymine in the gas phase. ${ }^{[32]}$ A series of ions is indeed detected at $\mathrm{m} / z, 112$ (base peak, not shown), 223, 334 and 445 that can be ascribed to [CH] $]^{+}$, $\left[\mathrm{C}_{2} \mathrm{H}\right]^{+},\left[\mathrm{C}_{3} \mathrm{H}\right]^{+}$and $\left[\mathrm{C}_{4} \mathrm{H}\right]^{+}$, respectively. Cationization of the nucleobase by $\mathrm{Na}^{+}$or $\mathrm{K}^{+}$is also observed.

Due to the very favored protonation of cytosine, ions arising from the interaction of the metal with cytosine are less intense than those observed with either uracil or thymine. Working with water/methanol mixtures of solvents slightly increase their relative intensity as compared to the use of pure water. Interaction between $\mathrm{Pb}^{2+}$ ions and cytosine gives rise to two series of ions. The first one correspond to $\left[\mathrm{Pb}(\mathrm{C})_{\mathrm{n}}-\mathrm{H}\right]^{+}(\mathrm{n}=1-5)$ species (at $m / z, 318,429,540,651$ and 762 in Figure 1a). Their intensities vary with the DP parameter. The $[\mathrm{Pb}(\mathrm{C})-\mathrm{H}]^{+}$ion $(\mathrm{m} / z$ 318) is weak at low DP but its intensity increases as the DP parameter is increased, since this species is generated by successive elimination of neutral cytosine from the higher homologues of the series, as checked by MS/MS and precursor ion scan experiments. Finally, we also managed to observe at low DP several doublycharged complexes of the type $\left[\mathrm{Pb}(\mathrm{C})_{\mathrm{p}}\right]^{2+}(\mathrm{p}=2-4)$, but their intensity is particularly weak with respect to the base peak $(\mathrm{m} / \mathrm{z} 112)$. Noteworthy, ions associated with the interaction of $\mathrm{Pb}^{2+}$ with the solvent are practically not detected.

To summarize, there is a competition between protonation of the nucleobase and its interactions with the metallic center. While observation of very intense lead/nucleobase complexes was straightforward with uracil and thymine, the situation is radically different with cytosine, (and also guanine and adenine), which is much more basic than uracil and thymine, and for which protonation is clearly overwhelming. Working with water/methanol solutions improves the detection of the complexes. Alternate way to generate these complexes by ESI is to use mononucleotides. We indeed observe that the $[\mathrm{Pb}(\mathrm{CMP})-\mathrm{H}]^{+}$complex obtained with $\mathrm{CMP}$ monoribonucleotide $(\mathrm{CMP}=$ cytidine-5'- 
monophosphate) gives rise, under CID conditions, to intense $[\mathrm{Pb}(\mathrm{C})-\mathrm{H}]^{+}$ions. ${ }^{[33]}$ This approach can be also used to form the complexes with the puric nucleobases. ${ }^{[34,35]}$

Low-energy CID spectra of $[\mathbf{P b}(\text { cytosine })-\mathbf{H}]^{+}$ion. The $[\mathrm{Pb}(\mathrm{C})-\mathrm{H}]^{+}$species involving ${ }^{208} \mathrm{~Pb}$ were selected and allowed to dissociate upon collision with nitrogen. MS/MS spectra were recorded at different collision energies between 10 to $30 \mathrm{eV}$ in the laboratory frame. The MS/MS spectrum obtained for $[\mathrm{Pb}(\mathrm{C})-\mathrm{H}]^{+}$ion at $\mathrm{E}_{\mathrm{lab}}=30 \mathrm{eV}$ (which corresponds to a collision energy of $2.4 \mathrm{eV}$ in the center of mass frame) is given in Figure 1b. A whole set of MS/MS spectra, including precursor ion scan mode and neutral loss experiments, lead to the fragmentation pattern given in Figure $1 \mathrm{~b}$.

Starting from the precursor ion, four distinct processes are observed. The first one, already encountered with uracil, thymine and 4-thiouracil ${ }^{[10,11]}$ corresponds to the formation of $[\mathrm{Pb}, \mathrm{N}, \mathrm{C}, \mathrm{O}]^{+}$ $(\mathrm{m} / \mathrm{z}, 250)$. The second process is associated with elimination of $43 \mathrm{amu}(\mathrm{H}, \mathrm{N}, \mathrm{C}, \mathrm{O})(\mathrm{m} / \mathrm{z} 2 \mathrm{275})$, and has

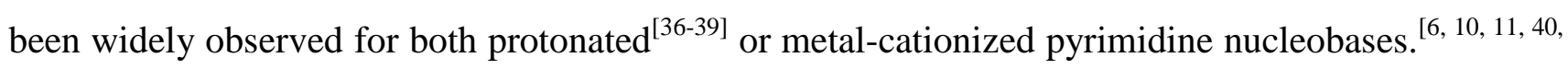
41] These two fragment ions further dissociate to generate the bare $\mathrm{Pb}^{+}$ion $(\mathrm{m} / \mathrm{z} 208)$. The third fragmentation is characterized by reduction of the metal and formation of the $[(\mathrm{C})-\mathrm{H}]^{+}$ion $(\mathrm{m} / z, 110)$, which in turn expels a 43 amu unit to generate the species detected at $\mathrm{m} / \mathrm{z} 67$. Finally, the predominant fragmentation process, which is characteristic of cytosine, is the formation of the $\left[\mathrm{PbNH}_{2}\right]^{+}$ion $(\mathrm{m} / \mathrm{z}, 224)$ by elimination of $\mathrm{C}_{4} \mathrm{H}_{2} \mathrm{~N}_{2} \mathrm{O}_{2}$. Formation of this latter species has been confirmed by accurate mass measurement with a LTQ-Orbitrap XL hybrid mass spectrometer (see Figure S1 of the Supporting Information).

The complexation (structure, energetics) of cytosine or cytosine-containing base pairs with metal ions has been extensively investigated ${ }^{[42-60]}$ contrarily to the behavior upon collision of metal/cytosine complexes, which is poorly described in the literature ${ }^{[61-63]}$. It has also attracted much less attention than metal/uracil complexes. Our purpose will be to compare these results with those deduced from previous studies. The interaction of cytosine with alkali and alkali-earth metal has been examined 
experimentally by mass spectrometry. Franska characterized the complexes formed between alkaliearth metals $(\mathrm{Mg}, \mathrm{Ca}, \mathrm{Sr}, \mathrm{Ba})$ and cytosine by electrospray using chloride salts. ${ }^{[61]}$ Ions of general formula $[\mathrm{MCl}+\mathrm{C}]^{+}$and $[\mathrm{M}(\mathrm{C})-\mathrm{H}]^{+}$ions were systematically detected. On the other hand, no MS/MS spectra were recorded during this particular study. The interactions of cytosine with alkali metals have been investigated by the kinetic method ${ }^{[62]}$ and by threshold collision-induced dissociation, ${ }^{[63]}$ to determine cytosine alkali metal affinities. $[\mathrm{M}+\mathrm{C}]^{+}$complexes were systematically generated. During the latter study, the only dissociation channel observed was the loss of intact cytosine. ${ }^{\text {[63] }}$ These results show that the reactivity upon collision of metal/nucleobases complexes involving monocations or dications is different since no formal deprotonation occurs for the former. The same is found when we examine the dissociations of protonated cytosine. The only common fragmentation observed for $[\mathrm{Pb}(\mathrm{C})-\mathrm{H}]^{+}$and $[\mathrm{C}] \mathrm{H}^{+}$ions is the elimination of $[\mathrm{H}, \mathrm{N}, \mathrm{C}, \mathrm{O}]$. Conversely, deamination, which is prominent for both protonated cytosine ${ }^{[14,38]}$ and 1-methylcytosine ${ }^{[37]}$ under various energetic regimes, is presently not observed with lead.

Finally, we also recorded the CID spectrum of the $\left[\mathrm{Pb}(\mathrm{C})_{\mathrm{n}}-\mathrm{H}\right]^{+}$complexes $(\mathrm{n}=2-5)$. The only fragment ion observed upon collision correspond to sequential losses of intact cytosine, leading to lower homologues.

\section{Structural characterization of the $[\mathrm{Pb}(\mathrm{C})-\mathrm{H}]^{+}$complex.}

Computational study. In order to complete these experimental findings, we have carried out theoretical calculations that enable us to describe the structures and bonding characteristics of the $[\mathrm{Pb}(\mathrm{C})-\mathrm{H}]^{+}$complex. Tautomerism of cytosine has been extensively studied, both experimentally ${ }^{[64-}$ 72] and theoretically. ${ }^{[73-87]}$ From these studies it is now accepted that cytosine may exist as three primary, low-energy forms, which are displayed in Scheme 1. The amino-oxo (keto) tautomer $\mathbf{1}$ is the "canonical" form present in DNA and RNA, and is predominant both for the solid pure compound and in solution (water). In the gas phase, the amino-hydroxy (enol) structure $\mathbf{2 b}$ dominates. The 
canonical form $\mathbf{1}$ is also present in significant abundance. Finally, the imino-oxo form denoted $\mathbf{3 b}$ has also been detected, as recently supported by a photoemission spectroscopy study. ${ }^{[70]}$ Theoretical studies also indicate that these forms are very close in energy. In fact, relative energies strongly depend on the level of calculations. ${ }^{[59,74,84]}$ Using various functionals and basis sets, DFT calculations consistently predict the keto form $\mathbf{1}$, as the most stable tautomer. On the other hand MP2 and $\operatorname{CCSD}(\mathrm{T})$ calculations find $\mathbf{2} \mathbf{b}$ to be the most stable neutral tautomer in the gas phase. In the present study, we considered six tautomers of cytosine to perform our calculations: the three aforementioned structures, the associated rotamers $\mathbf{2 a}$ and $\mathbf{3 a}$, and the second amino-oxo form, namely 4 (Scheme 1). These structures lie within $29 \mathrm{~kJ} / \mathrm{mol}$ in relative energies (see Supporting Information). Other tautomers, such as 2-hydroxy-4-iminodihydro $(3 \mathrm{H}, 4 \mathrm{H})$ pyrimidines, are less stable and were excluded.

Starting from these six forms, we considered that the deprotonation of cytosine to generate the $[\mathrm{Pb}(\mathrm{C})-\mathrm{H}]^{+}$complex may formally occur either on $\mathrm{N} 1, \mathrm{~N} 3$, the hydroxyl group or the amino group of the various neutral tautomers. The different structures found for the $[\mathrm{Pb}(\mathrm{C})-\mathrm{H}]^{+}$complexes are gathered in Figure 2, while the corresponding total and relative energies are summarized in Table 1. Note that a given form may arise from different tautomers. We have examined mono- and dicoordination modes and we have also considered that complexation may occur away from the deprotonation site. When looking at the Figure 2, there are two classes of structures. The first one is characterized by a metal lying in the plane of the nucleobase. These forms ((Cyt-H)-Pb1-14 and (Cyt-H)-Pb20) are obtained when the metal directly interacts with the deprotonation site. The second class of structures ((Cyt-H)-Pb15-19) is associated with a metal located out of the nucleobase plane. These structures are systematically obtained when the metal is located away from the deprotonation site and are much less stable than the planar ones. The second trend is that the most stable forms always correspond to bicoordinated species. In addition, in the case of the imino tautomer, structures 
with an imino hydrogen in a trans conformation with respect to the oxygen, are always favored.

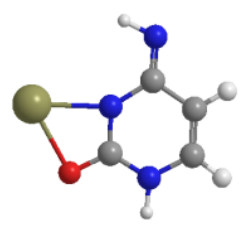

(Cyt-H)-Pb1

$+83.2$

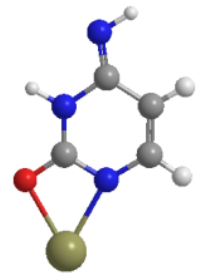

(Cyt-H)-Pb5

$+67.7$

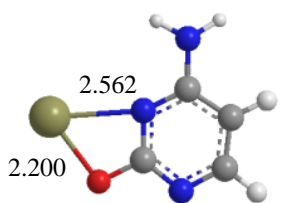

(Cyt-H)-Pb9

$+34.7$

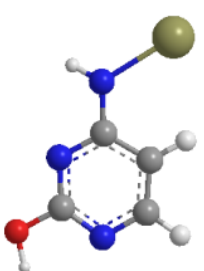

(Cyt-H)-Pb13

$+151.2$

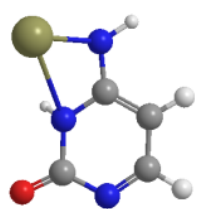

(Cyt-H)-Pb17

+198.5

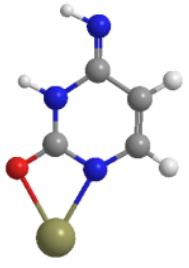

(Cyt-H)-Pb2

$+80.3$

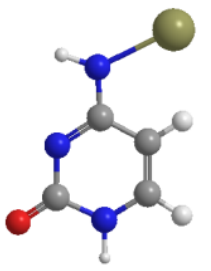

(Cyt-H)-Pb6

$+156.4$

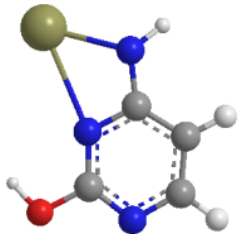

(Cyt-H)-Pb10

$+80.4$

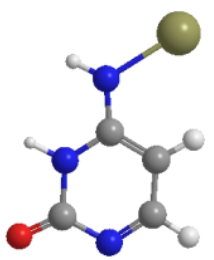

(Cyt-H)-Pb14

$+167.3$

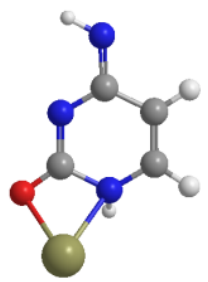

(Cyt-H)-Pb18

$+244.0$

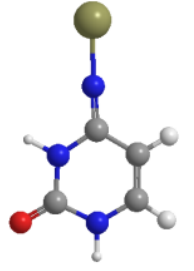

(Cyt-H)-Pb3

$+68.6$

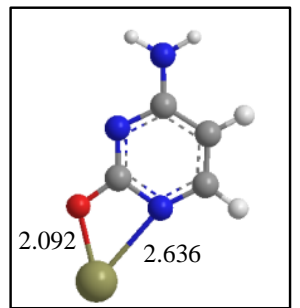

(Cyt-H)-Pb7

0.0

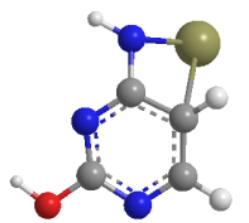

(Cyt-H)-Pb11

$+155.2$

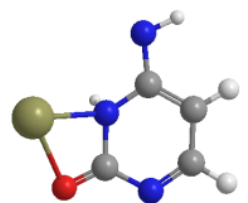

(Cyt-H)-Pb15

$+219.8$

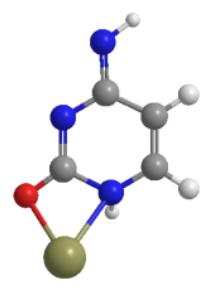

(Cyt-H)-Pb19

$+258.4$

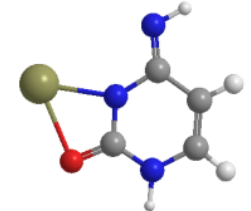

(Cyt-H)-Pb4

$+56.1$

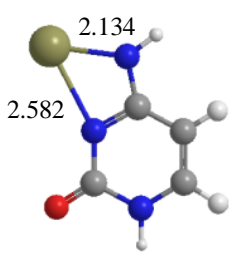

(Cyt-H)-Pb8

$+11.1$

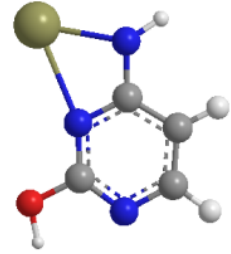

(Cyt-H)-Pb12 $+42.5$

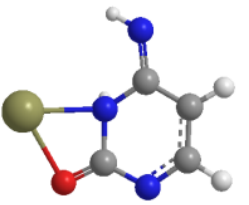

(Cyt-H)-Pb16 $+247.8$

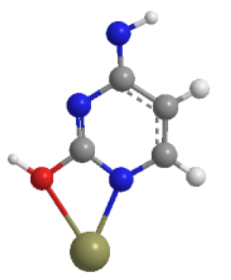

(Cyt-H)-Pb2O $+216.7$

Figure 2: Structure and B3LYP/6-311+G(3df,2p)//B3LYP/6-31(d,p)+ZPE relative energies $(\mathrm{kJ} / \mathrm{mol})$ of the lowest-energy structures obtained for $[\mathrm{Pb}(\mathrm{C})-\mathrm{H}]^{+}$complex. Bond lengths in Angströms 
The global minimum is (Cyt-H)-Pb7, and may result from the formal deprotonation of $\mathbf{1}, \mathbf{2 a}-\mathbf{b}$ at N1 and $\mathrm{O} 2$, respectively, which are the most acidic sites of these tautomers. ${ }^{[82]}$ It may also formally arise from N3 deprotonation of $\mathbf{4}$. This structure is characterized by a metal interacting with both N1 and the carbonyl group. By comparison with the associated deprotonated form (1-H)-c (see Supporting Information), interaction of the metal ion promotes the $\mathrm{sp}^{2}$ hybridization of the amino group. This binding scheme is sensibly more favorable than the situation where the metal interacts with both $\mathrm{N} 3$ and $\mathrm{O} 2((\mathbf{C y t}-\mathbf{H})-\mathbf{P b 9} ;+34.7 \mathrm{~kJ} / \mathrm{mol})$. The first local minimum $((\mathbf{C y t}-\mathbf{H})-\mathbf{P b 8})$ is located only 11 $\mathrm{kJ} / \mathrm{mol}$ above (Cyt-H)-Pb7 and may be viewed as the association between $\mathrm{Pb}^{2+}$ and deprotonated $\mathbf{1}$ or 3b. Its binding scheme is sensibly different since it involves two nitrogens, namely N3 and N4. Such a small energy difference suggests that a mixture of several structures might be generated in the gas-phase (vide infra). Comparison with relative energies obtained for (1-H)-b and (1-H)-c deprotonated forms of cytosine (section $\mathrm{S} 3$ of the Supporting Information) shows that $\mathrm{Pb}^{2+}$ enhances the gas-phase acidity of this particular amino hydrogen. Note also that structures with a similar binding mode but with a hydroxyl group ((Cyt-H)-Pb10 and (Cyt-H)-Pb12) are noticeably less stable. For these two latter forms, the metal is located slightly below the plane of the pyrimidic ring since N4 is not purely $\mathrm{sp}^{2}$ hybridized. It is also worth mentioning that when the metal interacts with both $\mathrm{O} 2$ and $\mathrm{N} 1$ or $\mathrm{N} 3$, the structures are systematically more stable when the exocyclic nitrogen (N4) bears two hydrogen atoms (amino group). Finally, the coordination of lead by a hydroxyl group is energetically disfavored. A structure was found starting from $\mathbf{2 a}$, characterized by a bidentate interaction involving $\mathrm{O} 2(\mathrm{H})$ and $\mathrm{N} 1((\mathbf{C y t}-\mathbf{H})-\mathbf{P b 2 0}))$. Starting from $\mathbf{2 b}, \mathrm{O} 2(\mathrm{H}) / \mathrm{N} 3$ interaction spontaneously evolves towards (Cyt-H)-Pb12 during optimization. The affinity of lead for $\mathrm{OH}$ groups is weaker than the affinity for carbonyl as it has already been observed when studying lead interactions with uracil and thymine ${ }^{[10]}$.

Our results tend to be slightly different from those reported for the interaction of keto-amino forms of neutral cytosine with alkali metals ${ }^{[42,46,50,52,59,62,63,88,89]}$ alkali earth metals ${ }^{[50,52,59,60]}$ or transition 
metals. ${ }^{[47,52,59]}$. Like our results, the most stable structure obtained with alkali metals involves the canonical cytosine form (1), but the binding scheme is different since alkali metals interact preferentially with $\mathrm{N} 3$ and $\mathrm{O} 2$, the interaction being mostly electrostatic and follows the orientation of the dipole moment of cytosine. The same trend is observed with alkali earth metals ( $\mathrm{Be}, \mathrm{Mg}, \mathrm{Ca}$,), the $\mathrm{O} 2 / \mathrm{N} 3$ interaction with canonical cytosine being particularly favored. Note however that the interactions with the other neutral keto-amino tautomer, namely 4 (see figure $\mathrm{S} 2$ ), has been considered only very recently by Kobayashi ${ }^{[59]}$, probably because this tautomer is not supposed to be present in the gas phase. It was demonstrated that complexes involving $(\mathbf{1} \mathrm{N} 3 / \mathrm{O} 2)$ and $(\mathbf{4} \mathrm{N} 1 / \mathrm{O} 2)$ are practically degenerate with $\mathrm{Mg}^{2+}, \mathrm{Ca}^{2+}$. Actually, the energy difference between N3/O2 and N1/O2 binding scheme for the $[\mathrm{Pb}(\mathrm{C})-\mathrm{H}]^{+}$complex is more pronounced since the $(\mathbf{C y t}-\mathbf{H})-\mathbf{P b} \mathbf{9}$ complex is $34.7 \mathrm{~kJ} / \mathrm{mol}$ less stable than the global minimum. If one again considers the study of Kobayashi ${ }^{[59]}$, a similar degeneracy is obtained with $\mathrm{Zn}^{2+}$. In general, the complexes issued from $(\mathbf{1} \mathrm{N} 3 / \mathrm{O} 2)$ form also represent the global minimum with the different transition metals studied.

The interactions involving other tautomers (amino-hydroxo and keto-imino) of neutral cytosine have also been investigated. Expectedly, as for keto-imino tautomers $\mathbf{3 a}$ and $\mathbf{3 b}$, the two nitrogen atoms bear a hydrogen, monodentate interactions are systematically favored for neutral cytosine, regardless of the nature of the metal ions. In our case, deprotonation of the nucleobase triggers the dicoordination of these tautomers by the metal, hence disfavoring monodentate forms such as (Cyt-H)-Pb6 or (Cyt-H)-Pb14.

For the sake of comparison, we also studied the interactions of $\mathrm{Pb}^{2+}$ ions with neutral cytosine, although the $[\mathrm{Pb}(\mathrm{C})]^{2+}$ complex was not presently observed experimentally. The various structures obtained are gathered in section S4 of the Supporting Information together with details about the calculations. Our results turn to be consistent with data obtained for other dications such as $\mathrm{Mg}^{2+}$, $\mathrm{Ca}^{2+}, \mathrm{Zn}^{2+}$ and $\mathrm{Mn}^{2+}$, because the most stable form involves the keto/amino tautomer $\mathbf{1}^{[47,52,59]}$ In addition, as recently noticed by Kobayashi for alkali earth metals or $\mathrm{Zn}^{2+}{ }^{[59]}$, structures in which $\mathrm{Pb}^{2+}$ 
interacts with $\mathrm{O} 2 / \mathrm{N} 3$ centers $((\mathbf{1 - P b})-\mathbf{a})$ or $\mathrm{O} 2 / \mathrm{N} 1$ centers $((\mathbf{4}-\mathbf{P b})-\mathbf{a})$ of the two keto/amino tautomers, are practically degenerate. On the other hand, the energy gap with the remaining structures is particularly important, and much more pronounced than for other metals. Without deprotonation of cytosine, monodentate forms can now be located for $\mathbf{3 a}$ and $\mathbf{3 b}$ tautomers.

In order to gain further insights about the nature of the interactions within $[\mathrm{Pb}(\mathrm{C})-\mathrm{H}]^{+}$complexes, we have carried out a natural population analysis (NPA) at the B3LYP/6-31G(d,p) level by means of the NBO program. ${ }^{[29]}$ Results obtained during the NBO study for the three most stable structures are reported in the Supporting Information (Table S5). NPA charges show a charge transfer from the nucleobase moiety to the lead atom, the local charge on $\mathrm{Pb}$ being $+1.49-1.52$. These values are smaller than those determined for the $\left[\mathrm{Pb}(\text { uracil) }-\mathrm{H}]^{+}\right.$complex $\left(+1.55-1.56^{[10]}\right)$, thus indicating a greater degree of electron transfer. According to the comparison of the natural charges observed in complexes with those of the corresponding deprotonated cytosine, lead complexation induces a strong polarization effect of the cytosine moiety, as illustrated by the increase of the negative charge for the interacting nitrogen and/or oxygen. In addition, the NBO analysis shows significant secondorder interaction energies between the empty orbitals of the metal ion and the lone pairs of the $\mathrm{N}$ and $\mathrm{O}$ atoms interacting with it. Natural electron configuration analysis indicates that the electron transfer is mostly in the $6 \mathrm{p}$ orbitals (typical values being: $6 \mathrm{~s}[1.93] 6 \mathrm{p}[0.57] \mathrm{sp}^{0.30}$ ). The $\mathrm{Pb}$ (II) lone pair is predominantly $6 \mathrm{~s}$, but is slightly polarized by a small 6 p contribution, ranging from 2.9 to $3.8 \%$.

Comparison of the bond lengths computed for the most stable $[\mathrm{Pb}(\mathrm{C})-\mathrm{H}]^{+}$complexes and their associated deprotonated forms (See Table S6) shows that the interaction of the metallic center promotes the activation of the $\mathrm{C}=\mathrm{O}$ and $\mathrm{C}-\mathrm{N}$ bonds interacting directly with $\mathrm{Pb}$. These polarization effects are also transmitted to the pyrimidic ring. For example, in the case of (Cyt-H)-Pb7 and (Cyt-H)-Pb9, the N3C4 and N1C6 bonds are significantly weakened (which is consistent with the loss of NCO moieties observed experimentally) while C4N4 is shortened. This is confirmed by the localization of the bond critical points (bcps) using Quantum Theory of Atoms In 
Molecules (QTAIM). ${ }^{[30,31]}$ Studies of the topological properties of the electron density indeed show that the electron density $\rho$ at the bcps always vary accordingly (Table S7). Note however that, as already observed for uracil ${ }^{[10]}$ and thiouracils ${ }^{[11]}$, the use of a pseudo-potential to describe the metal results in unreliable data for ellipticity $\varepsilon$ and Laplacian of the electron density $\nabla^{2} \rho$ at the BCPs located for $\mathrm{Pb}-\mathrm{X}(\mathrm{X}=\mathrm{N}$ or $\mathrm{O})$ bonds (see Table $\mathrm{S} 8$ for example).

IRMPD spectrum of the $[\mathrm{Pb}(\mathrm{C})-\mathrm{H}]^{+}$complex. The computational study has shown that several $[\mathrm{Pb}(\mathrm{C})-\mathrm{H}]^{+}$structures are close in energy, suggesting that a mixture of forms might be generated within the mass spectrometer. This is the case for example of the [Na-cytosine $]^{+}$complex, as Rodgers and co-workers determined that tautomerization of cytosine occurred both during complex formation and CID of the complex. ${ }^{[63]}$ Consequently, in order to gain further insights about the presence of a mixtures of structures in the gas phase, we have recorded the IRMPD spectrum of the $[\mathrm{Pb}(\mathrm{C})-\mathrm{H}]^{+}$ complex.

IRMPD spectroscopy has been widely applied to characterize the structure of metal-cationized complexes $^{[90-99]}$, and notably of metal/DNA blocks species. ${ }^{[33,34,100-104]}$ Presently, IRMPD spectra have been recorded in the $1000-1900 \mathrm{~cm}^{-1}$ energy range. On resonance with an infrared active mode of the mass-selected $[\mathrm{Pb}(\mathrm{C})-\mathrm{H}]^{+}$complex, the elimination of the $[\mathrm{H}, \mathrm{N}, \mathrm{C}, \mathrm{O}]$ moiety $(\mathrm{m} / \mathrm{z} 275)$ is observed and the experimental spectrum presently reported was obtained by considering this photofragment. The IRMPD spectrum corresponds to the fragmentation efficiency, defined as $\ln \left[\right.$ Parent/(Parent+Fragments)], as a function of the photon wavenumber. Recently ${ }^{[105]}$, it has been demonstrated that this data treatment allows a better comparison between IRMPD intensities and calculated infrared absorption spectra, and a better spectral resolution than other analysis methods. The experimental IRMPD spectrum of the $[\mathrm{Pb}(\mathrm{C})-\mathrm{H}]^{+}$ion is given in Figure 3a. This spectrum shows several pronounced features at $1270-1310 \mathrm{~cm}^{-1}$, at 1423 and $1760 \mathrm{~cm}^{-1}$, and several absorptions from 1460 to $1640 \mathrm{~cm}^{-1}$ and notably a very intense signal at $1610 \mathrm{~cm}^{-1}$. Other weaker bands appear at 
about 1060 and $1360 \mathrm{~cm}^{-1}$. The assignment of the IRMPD spectrum is based on its comparison with the spectra computed for various low-energy lying isomers. The vibrational bands computed for (Cyt-H)-Pb7, (Cyt-H)-Pb8 and (Cyt-H)-Pb9 are summarized in Table 2. In making these comparisons, one should keep in mind that because of the complex nature of the IRMPD process, ${ }^{[106-}$ ${ }^{108]}$ the computed IR intensities, which assume single photon absorption, may not correspond well with the experimental abundances. To make the comparison easier computed absorption crosssections represented in Figure 3 have been taken assuming a Gaussian profile $\left(\mathrm{FWHM}=15 \mathrm{~cm}^{-1}\right)$ for each calculated infrared band.

Figure 3 shows an overall good agreement between the experimental spectrum and the IR absorption spectrum computed for the global minimum (Cyt-H)-Pb7. The vibrational modes of $[\mathrm{Pb}(\mathrm{C})-\mathrm{H}]^{+}$complex may be assigned as described in Table 2. The IRMPD features centered around $1280 \mathrm{~cm}^{-1}$ may be interpreted as a ring breathing mode, implying notably the stretch of the N1C2 bond, while the small features detected at 1060 and $1360 \mathrm{~cm}^{-1}$ may correspond to the $\mathrm{NH}_{2}$ rocking mode and $\mathrm{CH}$ bending mode, respectively. The signal observed at $1423 \mathrm{~cm}^{-1}$ could be attributed to the combined bending C-N-H and N3C4 stretching modes. Absorptions observed between 1460 and 1550 wavenumbers may be interpreted as a combination of bending $\mathrm{C}-\mathrm{N}-\mathrm{H}$ and the elongation vibration of both $\mathrm{C} 2 \mathrm{~N} 3$ and $\mathrm{C} 4 \mathrm{C} 5$ bonds. Finally, the very intense feature centered around 1610 $\mathrm{cm}^{-1}$ may be associated with the $\mathrm{NH}_{2}$ scissoring mode, and the $\mathrm{C} 4 \mathrm{~N} 4$ stretching mode, computed at $1605 \mathrm{~cm}^{-1}$ and $1619 \mathrm{~cm}^{-1}$, respectively.

The $\mathrm{C}=\mathrm{O}$ stretching mode constitutes an excellent infrared diagnostic of the presence of bare keto forms. The DFT-calculated IR absorption spectrum of (Cyt-H)-Pb8, which is located only $11 \mathrm{~kJ} / \mathrm{mol}$ above the global minimum (Cyt-H)-Pb7, and in which the metal does not interact with the carbonyl 


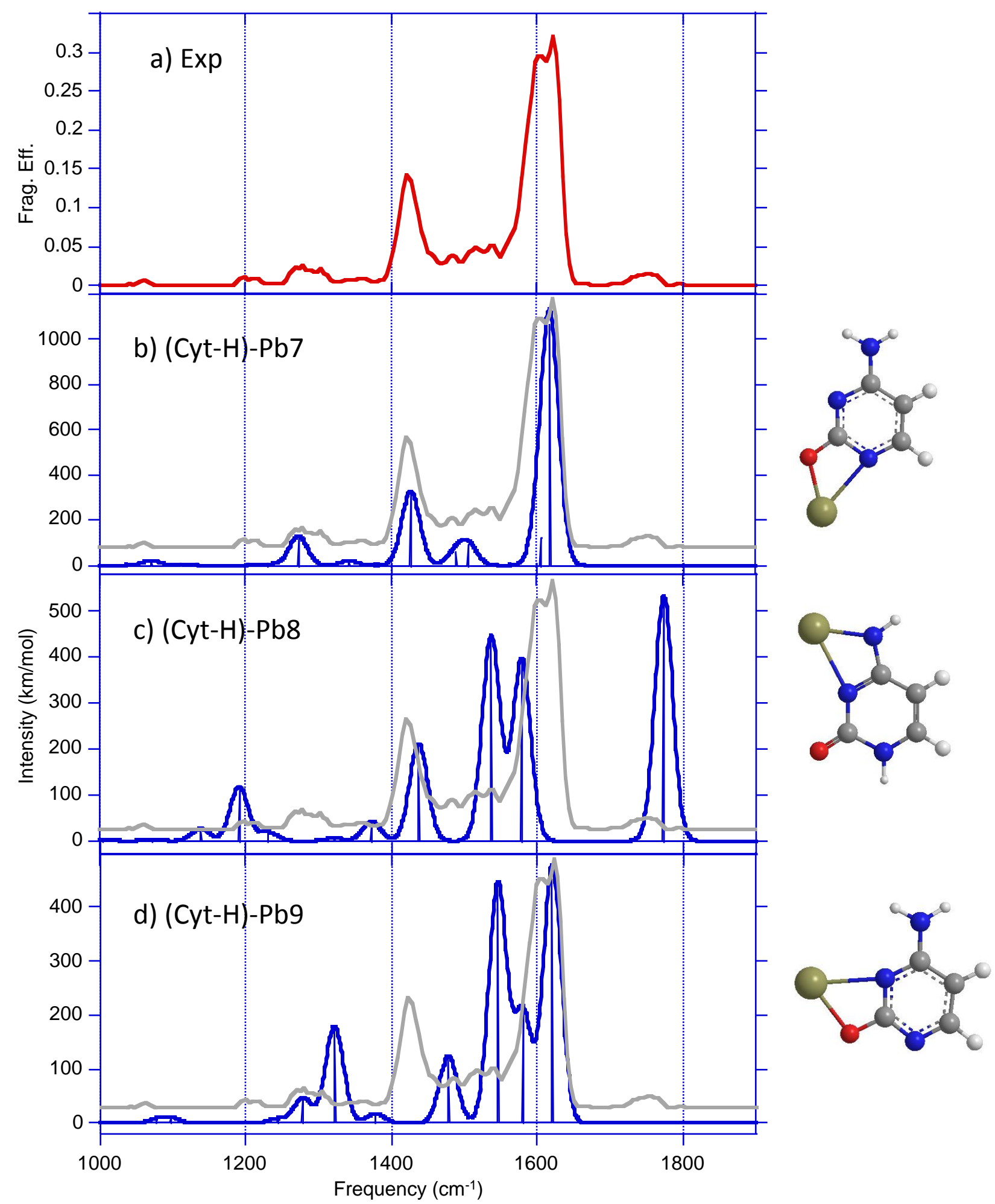

Figure 3: IRMPD spectrum (a) obtained for the $[\mathrm{Pb}(\mathrm{C})-\mathrm{H}]^{+}$complex compared to DFT-computed IR absorption spectra (b-d) of structures representative of different binding schemes.

group, is given in Figure 3c. This spectrum exhibits a strong absorption at $1773 \mathrm{~cm}^{-1}$ corresponding to the free $\mathrm{C} 2=\mathrm{O} 2$ stretching mode. This band is consistent with the experimental signal at $1760 \mathrm{~cm}^{-1}$. 
In addition, for the sake of comparison, the IRMPD spectrum of the $\left[\mathrm{Pb}(\text { uracil) }-\mathrm{H}]^{+}\right.$complex, recorded the same day, is given in Figure 4a and is compared to the DFT-calculated IR absorption of the global minimum found for this system (Figure 4b). ${ }^{[10]}$ A very good agreement is observed between the two spectra. Uracil presents two carbonyl groups and only one of these groups interacts with the metal. The very intense feature observed experimentally at about $1755 \mathrm{~cm}^{-1}$, corresponds to the free $\mathrm{C}=\mathrm{O}$ stretch. This result indicates that this stretching mode can be particularly intense under IRMPD conditions. Note that the calculated infrared intensity associated to the CO stretch is also very large (Figure 4b). Consequently, even if rigorous quantitation cannot be made, one may deduce from the low intensity of the $\mathrm{C}=\mathrm{O}$ stretch in Figure 3a that the (Cyt-H)-Pb8 form is generated in minor proportion. Note that this form may also account for the experimental signal detected around $1200 \mathrm{~cm}^{-1}$ and to the experimental signals measured from 1400 to $1580 \mathrm{~cm}^{-1}$.

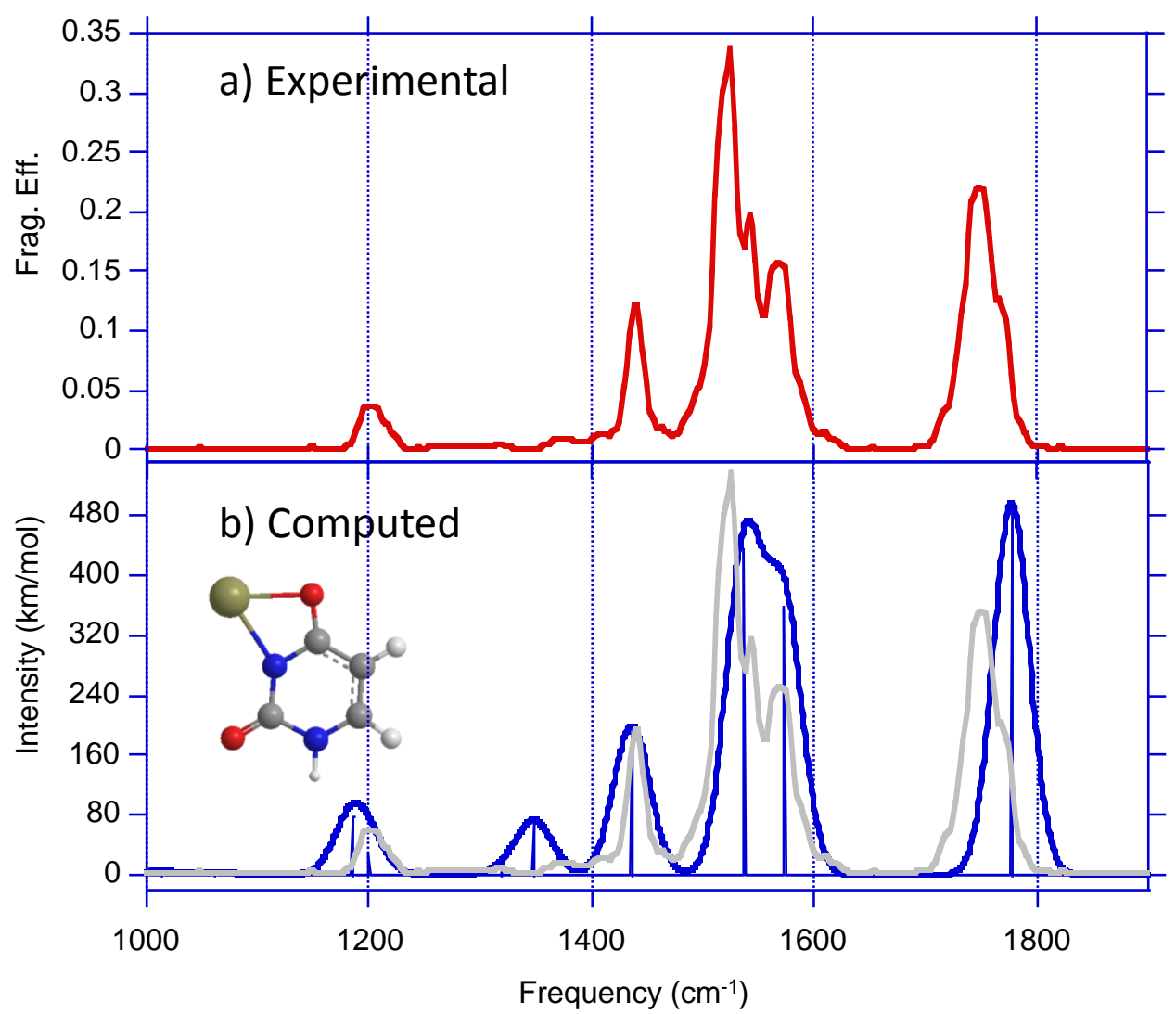

Figure 4: IRMPD spectrum (a) obtained for the $[\mathrm{Pb} \text { (uracil) }-\mathrm{H}]^{+}$complex compared to DFTcomputed IR absorption spectrum of the global minimum. See Ref. [10] for details 
The experimental signal detected at about $1600 \mathrm{~cm}^{-1}$ turns to be rather broad, and according to Figure $3 \mathrm{c}$ and $3 \mathrm{~d}$, might also correspond to several vibration modes of the (Cyt-H)-Pb8 and (CytH)-Pb9. However, the very active mode computed at $1322 \mathrm{~cm}^{-1}$ for the latter structure do not correspond to any experimental signal. Conversely, this structure cannot account for the absorption measured at $1423 \mathrm{~cm}^{-1}$. Furthemore, as (Cyt-H)-Pb9 is located $34.7 \mathrm{~kJ} / \mathrm{mol}$ above the global minimum, its presence, assuming a Maxwell-Boltzmann population distribution, seems unlikely. In conclusion, IRMPD experiments suggest that electrospray ionization leads to a mixture of the two most stable computed structures, the N1/O2 coordination mode being clearly overwhelming.

\section{Unimolecular reactivity of the $[\mathrm{Pb}(\mathrm{C})-\mathrm{H}]^{+}$complex.}

In order to complement our experimental CID data, we have attempted to explore the topology of the $[\mathrm{Pb}(\mathrm{C})-\mathrm{H}]^{+}$potential energy surface, so as to propose dissociation mechanisms accounting for the formation of the most intense fragments, namely $m / z 275,250$ and 224 . We will present this surface in three different sections.

Formation of the $\left[\mathrm{PbNH}_{2}\right]^{+}(\mathrm{m} / z$ 224). As indicated in previous sections, the dominant peak in the MS/MS spectrum corresponds to the formation of the $\left[\mathrm{PbNH}_{2}\right]^{+}$species at $\mathrm{m} / \mathrm{z} 224$. Obviously, the most favorable precursors for this fragmentation are, a priori, complexes having an amino group. Starting from the global minimum, isomerization into $(\mathbf{C y t}-\mathbf{H})-\mathbf{P b} \mathbf{9}$ through rotation of the metal around the $\mathrm{C} 2 \mathrm{O} 2$ bond is associated with an activation barrier of $102 \mathrm{~kJ} / \mathrm{mol}$ (Figure 5). Further migration of the metal towards the amino group occurs out of the plane of the nucleobase and triggers the simultaneous cleavage of the pyrimidic ring, yielding the acyclic intermediate M5 lying 210 $\mathrm{kJ} / \mathrm{mol}$ above the global minimum. This corresponds to the rate-limiting step, the associated $\begin{array}{lllllll}\text { transition } & \text { state } & \text { TS9-M5 being located } & 258 & \mathrm{~kJ} / \mathrm{mol} & \text { above }\end{array}$ (Cyt-H)-Pb7. M5 is characterized by a metal interacting with both N3 and N4. The last step corresponds to the disappearance of the $\mathrm{N} 3-\mathrm{Pb}$ interaction through an activation barrier of $46 \mathrm{~kJ} / \mathrm{mol}$ 
above M5, leading to the ion neutral complex M6, which in turn gives rise ultimately to $\left[\mathrm{Pb}\left(\mathrm{NH}_{2}\right)\right]^{+}$ and an acyclic 3-isocyanato-2-propenenitrile molecule.

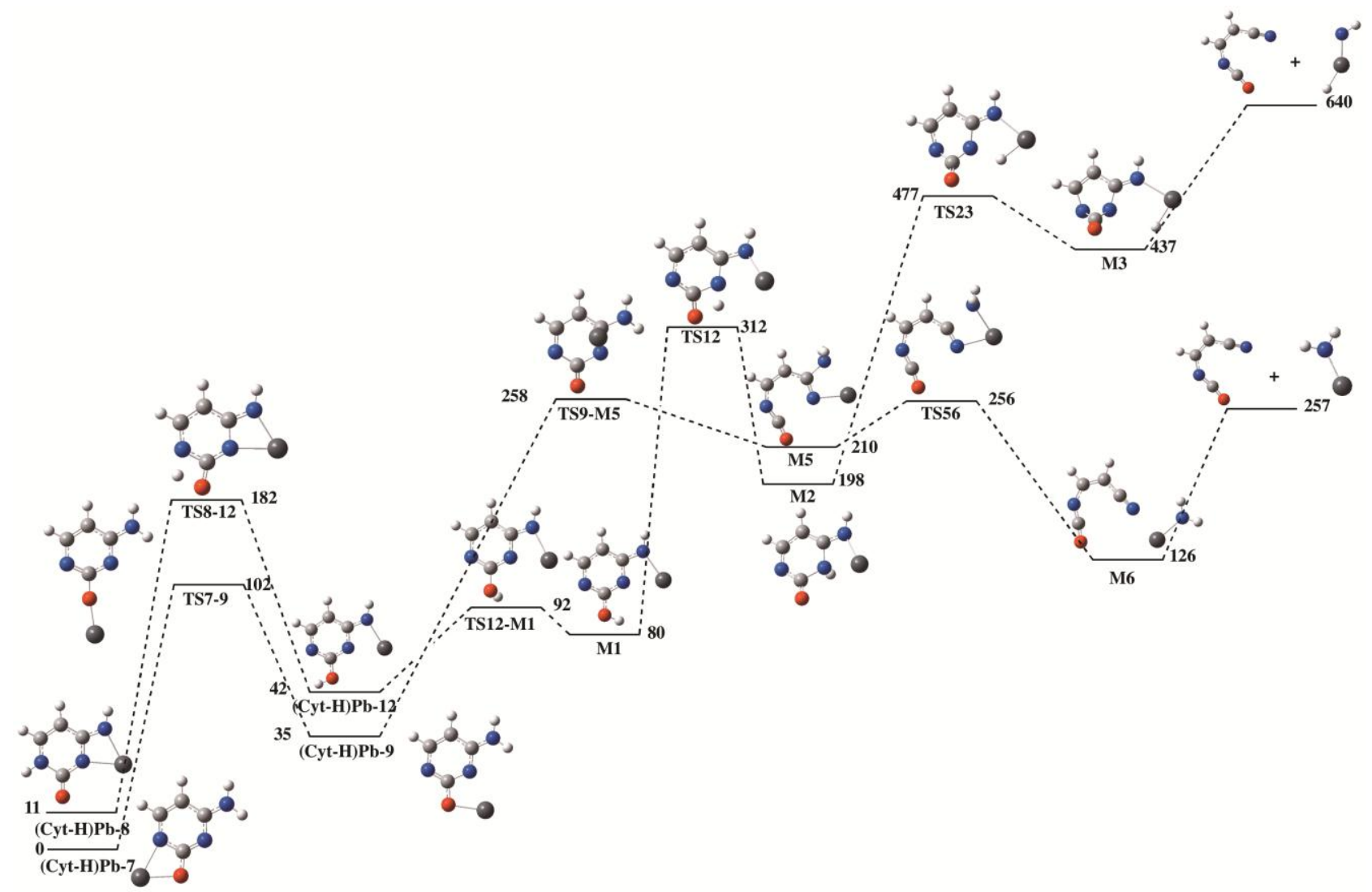

Figure 5. Energy profiles associated with the formation of the $\left[\mathrm{PbNH}_{2}\right]^{+}$ion. Relative energies $(\mathrm{kJ}$ $\mathrm{mol}^{-1}$ ) are calculated, with respect to the global minimum (Cyt-H)-Pb7 at the B3LYP/6$311++\mathrm{G}(3 \mathrm{df}, 2 \mathrm{p}) / / \mathrm{B} 3 \mathrm{LYP} / 6-31 \mathrm{G}(\mathrm{d}, \mathrm{p})$ level of theory.

We have also explored the possible formation of $[\mathrm{HPbNH}]^{+}$from the second most stable complex, (Cyt-H)-Pb8, because IRMPD results suggest that this form may also be present in the gas phase. This pathway is globally characterized by the migration of a hydroxyl hydrogen onto the metal. This first step corresponds to the formation of the enol-imino form (Cyt-H)-Pb12 through a 1,3-H shift. This step is associated with an activation barrier of $171 \mathrm{~kJ} / \mathrm{mol}$ with respect to the initial structure. The second step corresponds to the rotation of the hydroxyl group yielding M1, followed by a 1,3 proton shift leading to $\mathbf{M 2}$. The activation barrier associated to this latter proton shift is high (232 $\mathrm{kJ} / \mathrm{mol}$ ). The last step corresponds to the migration of the hydrogen onto the metal, leading to the $\mathbf{M 3}$ 
intermediate. $\mathbf{M} 3$ finally dissociates to generate $[\mathrm{HPbNH}]^{+}$and again 3-isocyanato-2-propenenitrile. One can see that from the thermodynamic viewpoint, this mechanism is $383 \mathrm{~kJ} / \mathrm{mol}$ less favorable than the mechanism starting from (Cyt-H)-Pb7. Consequently, the $m / z 224$ ion should correspond to the formation of $\left[\mathrm{Pb}\left(\mathrm{NH}_{2}\right)\right]^{+}$.

Two other mechanism starting from (Cyt-H)-Pb6 and (Cyt-H)-Pb14 are given in the Supporting Information (section S9). One can notably see that the elimination of a cyclic $\mathrm{C}_{4} \mathrm{H}_{2} \mathrm{~N}_{2} \mathrm{O}$ molecule is $343 \mathrm{~kJ} / \mathrm{mol}$ less favorable than the elimination of 3-isocyanato-2-propenenitrile.

Elimination of $\boldsymbol{H}, \boldsymbol{N}, \boldsymbol{C}, \boldsymbol{O}$. The second important fragmentation is associated with the elimination of a $43 \mathrm{amu}$ neutral entity leading to $\mathrm{m} / \mathrm{z} 275$. Two different mechanisms accounting for the elimination of $[\mathrm{H}, \mathrm{N}, \mathrm{C}, \mathrm{O}]$ are summarized in Figure 6. Both have their origin in $(\mathbf{C y t}-\mathbf{H}) \mathbf{P b} \mathbf{9}$, which, as already discussed before, can be generated from the global minimum by rotation. The first two steps are common to both mechanisms and are characterized by ring opening through the cleavage of the C2N3 bond, followed by a rotation around the C4C5 bond, to yield the M10 intermediate, located $140 \mathrm{~kJ} / \mathrm{mol}$ above the global minimum. These two first steps are associated with moderate activation barriers. Starting from M10, two different processes can be envisaged. The most favorable one corresponds to a 1,5 proton shift from $\mathrm{N} 4$ to $\mathrm{N} 1$, which induces the formation of both the $\mathrm{HNCO}$ moiety and a C4-ring within an ion/neutral complex (M11). Final elimination of HNCO leads to a cyclic $m / z 275$ species. The second process, much less favorable, implies proton shift from C6 to N1, leading to M12 through an activation barrier located $622 \mathrm{~kJ} / \mathrm{mol}$ above (Cyt-H)-Pb7. Further elimination of $\mathrm{HNCO}$ results in an acyclic structure $147 \mathrm{~kJ} / \mathrm{mol}$ less stable than the cyclic one. Comparison with Figure 5 shows that the two mechanisms are both kinetically and energetically disfavored with respect to the formation of $m / z$ 224. This finding is consistent with lower abundance of the $m / z 275$ ion, as compared to the intensity of the $m / z 224$ ion (see figure $1 b$ ). 


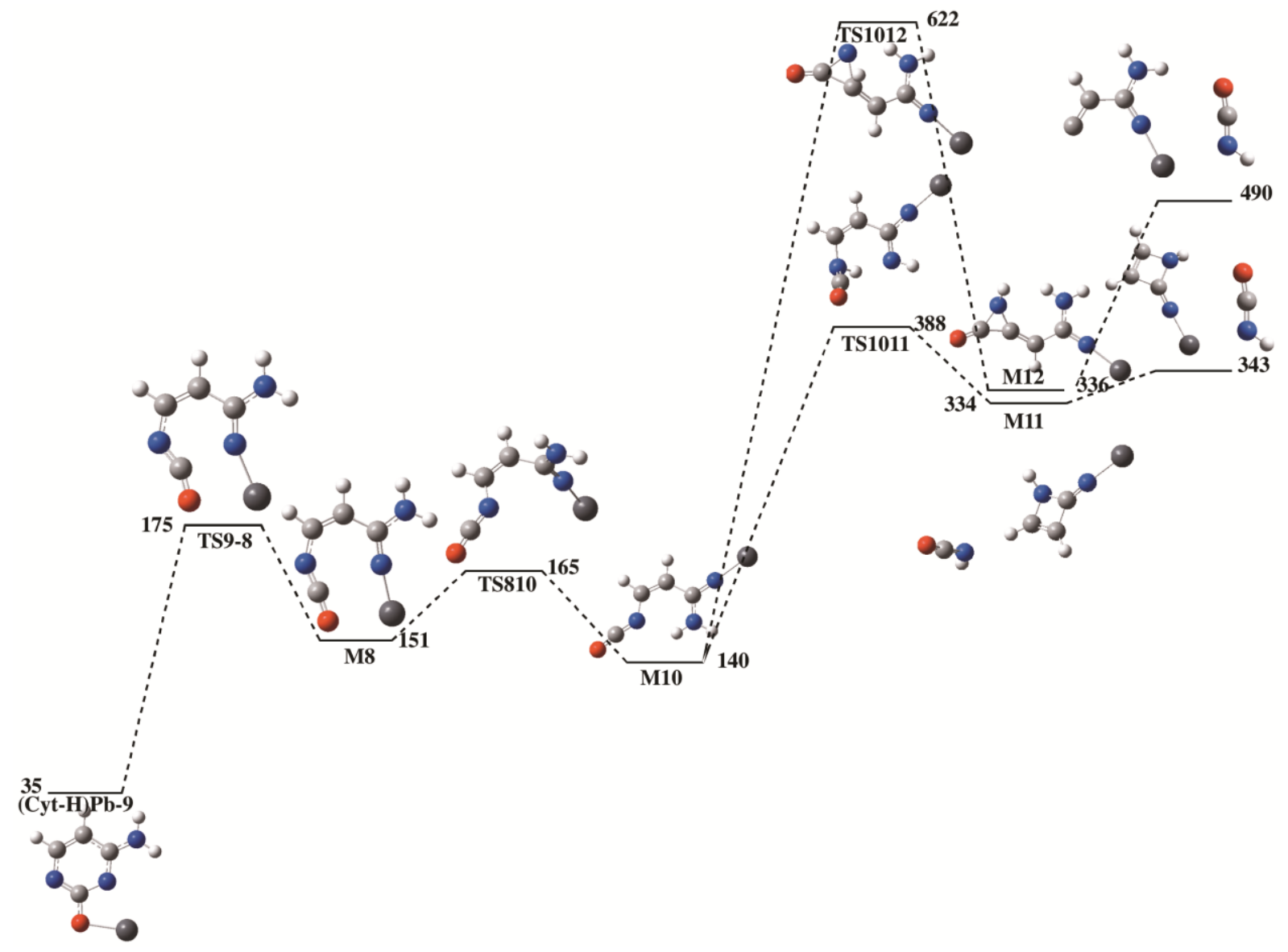

Figure 6. Energy profiles associated with the formation of the $m / z 275$ fragment ion by elimination isocyanic acid. Relative energies $\left(\mathrm{kJ} \mathrm{mol}^{-1}\right)$ are calculated with respect to the global minimum (CytH)-Pb7 at the B3LYP/6-311++G(3df,2p)//B3LYP/6-31G(d,p) level of theory.

Formation of the $[\mathrm{PbN}, \mathrm{C}, \mathrm{O}]^{+}(\mathrm{m} / \mathrm{z}, 250)$. Finally we also investigated the formation of $[\mathrm{Pb}, \mathrm{N}, \mathrm{C}, \mathrm{O}]^{+}$, detected experimentally in weak abundance at $m / z$ 250. Again, the (Cyt-H)-Pb9 complex seems to be a key intermediate for the formation of this ion. In fact by reaching the minimum M8, as has been cited above, two exit channels could be proposed (see figure 7). The first one consists in the formation of $[\mathrm{PbOCN}]^{+}$directly from this complex by a barrierless process and which lies at about $621 \mathrm{~kJ} / \mathrm{mol}$ above the global minimum. The second compound that could be suggested comes from a 1,3 hydrogen migration in minimum M8, as first step, to yield complex M9. This latter could dissociate to give $[\mathrm{PbNCO}]^{+}$as a final product. The resultant exit channel is about $364 \mathrm{~kJ} / \mathrm{mol}$ above the global minimum. This could be considered as the most probable process for the formation of the $m / z 250$ ion. Note that another possible fragmentation process leading to this ion, appears 
thermodynamically more favored (see figure S10). It implies as precursor the (Cyt-H)-Pb8 structure which may be formed in minor amounts in the gas phase and which is not easily connected to the global minimum (Cyt-H)-Pb7.

Again, it is worth noting that these mechanisms are less favorable than those leading to $m / z 224$, in agreement with the very high intensity of this latter ion.

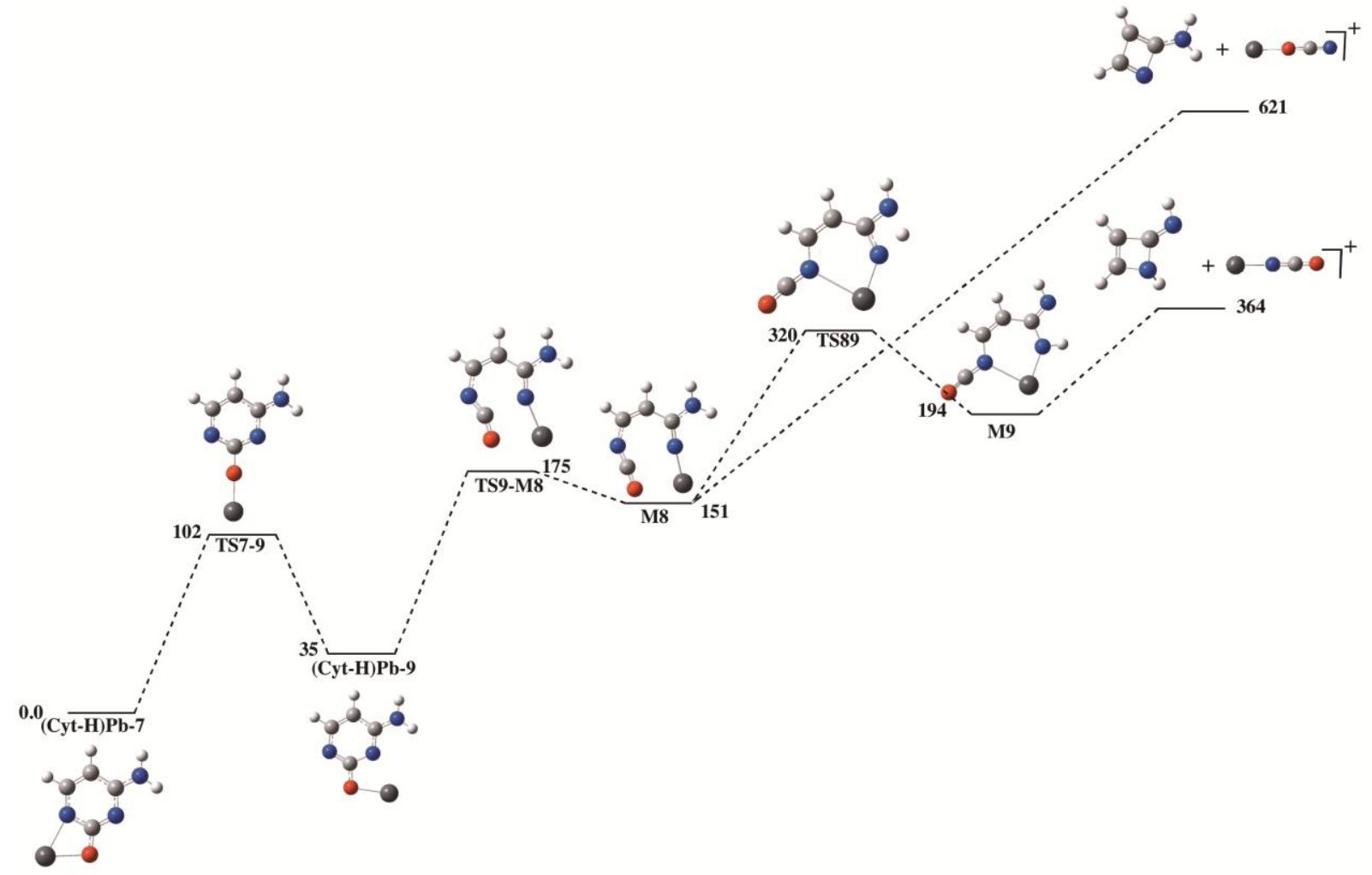

Figure 7. Energy profiles associated with the formation of the $[\mathrm{PbN}, \mathrm{C}, \mathrm{O}]^{+}$ion $(\mathrm{m} / \mathrm{z} 250)$. Relative energies $\left(\mathrm{kJ} \mathrm{mol}^{-1}\right)$ are calculated with respect to the global minimum $(\mathbf{C y t}-\mathbf{H})-\mathbf{P b} 7$ at the B3LYP/6-311++G(3df,2p)//B3LYP/6-31G(d,p) level of theory.

Additional information could be obtained by performing RRKM analysis or dynamics simulations. The latter approach recently proved to provide novel insights on the MS/MS fragmentation processes of molecules of biological interest. ${ }^{[109,110]}$ But this is clearly beyond the scope of the present paper. 


\section{Conclusion}

This study illustrates the fruitful interplay between CID, IRMPD and theoretical calculations to explore the interactions taking place in the gas phase between $\mathrm{Pb}^{2+}$ and cytosine. Positive-ion electrospray mass spectra show that lead(II) ions interact with cytosine to generate both singly and doubly-charged species in the gas phase. The most abundant complex detected, $[\mathrm{Pb}(\text { cytosine })-\mathrm{H}]^{+}$ has been extensively studied by MS/MS experiments, IRMPD spectroscopy and quantum calculations. Its unimolecular reactivity upon collision is sensibly different from that observed with uracil. Comparison between DFT-computed IR spectra and IRMPD data indicates that two structures, characterized by the interaction of the metal with the deprotonated canonical keto-amino tautomer of cytosine, may be generated in the gas phase. Overall, there is a good agreement between experimental IRMPD spectrum recorded between 1000 and $1900 \mathrm{~cm}^{-1}$ and the calculated infrared absorption spectrum of the global minimum, a bidentate form involving both $\mathrm{N} 1$ and $\mathrm{O} 2$ electronegative centers, a coordination scheme which is different from those described for other metals. A minor fraction of the second most stable form slightly higher in energy is also evidenced by the presence of a weak IRMPD signal at $\sim 1760 \mathrm{~cm}^{-1}$.

The DFT study also points out a significant charge transfer from the nucleobase to low-lying $\mathrm{p}$ orbitals of the metal and strong polarization of the base upon complexation. Several mechanisms are proposed to account for the formation of the fragment ions observed by CID. The various potential energy surfaces associated with these mechanisms are consistent with the high abundance of the $\left[\mathrm{PbNH}_{2}\right]^{+}$fragment ion.

\section{Acknowledgements}

The authors wish to thank the CLIO team (J. M. Ortega, C. Six, G. Perilhous, J. P. Berthet) as well as P. Maître and V. Steinmetz for their support during the experiments. This work has been partially supported by the DGI Projects no. CTQ2012-35513-C02-01, by the Project MADRISOLAR2, Ref.: 
S2009PPQ/1533 of the Comunidad de Madrid, and by Consolider on Molecular Nanoscience CSC2007-00010. A generous allocation of computing time at the Centro de Computación Científica of the UAM is also acknowledged.

\section{Bibliography}

[1] E. A. Ramoska, H. A. Spiller, M. Winter, D. Borys Ann. Emerg. Med. 1993, 22, 196-200.

[2] B. Halliwell, J. M. C. Gutteridge Arch. Biochem. Biophys. 1986, 246, 501-514.

[3] M. J. Burkitt Methods Enzymol. 1994, 234, 66-79.

[4] W. Bal, K. S. Kasprzak Toxicol. Lett. 2002, 127, 55-62.

[5] A. Lamsabhi, M. Yáñez, J.-Y. Salpin, J. Tortajada, Gas phase chemistry of organocopper compounds, John Wiley \& Sons, Chichester, 2009.

[6] C. Trujillo, A. Lamsabhi, O. Mo, M. Yanez, J. Y. Salpin Int. J. Mass Spectrom. 2011, 306, $27-$ 36.

[7] W. R. Farkas Biochim. Biophys. Acta. 1968, 155, 401-409.

[8] J. Swiatek, B. Gulanowski Acta Biochim. Pol. 1990, 37, 7-20.

[9] I. Smirnov, R. H. Shafer J. Mol. Biol. 2000, 296, 1-5.

[10] S. Guillaumont, J. Tortajada, J. Y. Salpin, A. M. Lamsabhi Int. J. Mass Spectrom. 2005, 243, 279-293.

[11] J. Y. Salpin, S. Guillaumont, J. Tortajada, A. M. Lamsabhi J. Am. Soc. Mass Spectrom. 2009, 20, 359-369.

[12] A. K. Chandra, M. T. Nguyen, T. Uchimaru, T. Zeegers-Huyskens J. Phys. Chem. A. 1999, $103,8853-8860$.

[13] J. K. Wolken, F. Turecek J. Am. Soc. Mass Spectrom. 2000, 11, 1065-1071.

[14] J. Y. Salpin, S. Guillaumont, J. Tortajada, L. MacAleese, J. Lemaire, P. Maitre ChemPhysChem. 2007, 8, 2235-2244.

[15] I. V. Chernushevich, A. V. Loboda, B. A. Thomson J. Mass Spectrom. 2001, 36, 849-865.

[16] C. Trujillo, O. Mo, M. Yanez, J. Tortajada, J. Y. Salpin J. Phys. Chem. B. 2008, 112, 54795486.

[17] A. Eizaguirre, O. Mo, M. Yanez, J. Y. Salpin Phys. Chem. Chem. Phys. 2011, 13, 1840918417. 
[18] L. MacAleese, A. Simon, T. B. McMahon, J. M. Ortega, D. Scuderi, J. Lemaire, P. Maitre Int. J. Mass Spectrom. 2006, 249, 14-20.

[19] B. Chiavarino, M. E. Crestoni, S. Fornarini, J. Lemaire, P. Maitre, L. MacAleese J. Am. Chem. Soc. 2006, 128, 12553-12561.

[20] A. Simon, L. MacAleese, P. Maitre, J. Lemaire, T. B. McMahon J. Am. Chem. Soc. 2007, $129,2829$.

[21] R. Prazeres, F. Glotin, C. Insa, D. A. Jaroszynski, J. M. Ortega Eur. Phys. J. D. 1998, 3, 8793.

[22] M. J. Frisch, G. W. Trucks, H. B. Schlegel, G. E. Scuseria, M. A. Robb, J. R. Cheeseman, V. G. Zakrzewski, J. J. A. Montgomery, T. Vreven, K. N. Kudin, J. C. Burant, J. M. Millam, S. S. Iyengar, J. Tomasi, V. Barone, B. Mennucci, M. Cossi, G. Scalmi, N. Rega, G. A. Petersson, H. Nakatsuji, M. Hada, M. Ehara, K. Toyota, R. Fukuda, J. Hasegawa, M. Ishida, T. Nakajima, Y. Honda, O. Kitao, C. Adamo, J. Jaramillo, R. Gomperts, R. E. Stratmann, O. Yazyev, J. Austin, R. Cammi, C. Pomelli, J. Ochterski, P. Y. Ayala, K. Morokuma, G. A. Voth, P. Salvador, J. J. Dannenberg, V. G. Zakrzewski, S. Dapprich, A. D. Daniels, M. C. Strain, O. Farkas, D. K. Malick, A. D. Rabuck, K. Raghavachari, J. B. Foresman, J. V. Ortiz, Q. Cui, A. G. Baboul, S. Clifford, J. Cioslowski, B. B. Stefanov, G. Liu, A. Liashenko, P. Piskorz, I. Komaromi, R. L. Martin, D. J. Fox, T. Keith, M. A. Al-Laham, C. Y. Peng, A. Nanayakkara, M. Challacombe, P. M. W. Gill, B. Johnson, W. Chen, M. W. Wong, C. Gonzalez, J. A. Pople in, Vol. (Ed.^Eds.: Editor), Gaussian, Inc., City, 2003.

[23] C. Lee, W. Yang, R. G. Parr Phys. Rev. B. 1988, 37, 785-789.

[24] A. D. Becke J. Chem. Phys. 1993, 98, 5648-5652.

[25] C. Gonzalez, H. B. Schlegel J. Chem. Phys. 1989, 90, 2154-2161.

[26] W. Küchle, M. Dolg, H. Stoll, H. Preuss Mol. Phys. 1991, 6, 1945-1963.

[27] J. Y. Salpin, J. Tortajada, M. Alcamí, O. Mó, M. Yáñez Chem. Phys. Lett. 2004, 383, 561565.

[28] F. Aguilar-Galindo, M. M. Montero-Campillo, M. Yáñez, O. Mó Chem. Phys. Lett. 2014, $598,91-95$.

[29] E. D. Glendening, A. E. Reed, F. Weinhold in NBO version 3.1.

[30] R. F. W. Bader, Atoms in molecules : a quantum theory, Clarendon Press ; Oxford University Press, Oxford, New York, 1990.

[31] R. F. W. Bader, J. R. Cheeseman in AIMPAC Programs. 2000.

[32] NIST Computational Chemistry Comparison and Benchmark Database. NIST Standard Reference Database Number 101 . Russell D. Johnson III 2005.

[33] J.-Y. Salpin, L. Gamiette, J. Tortajada, T. Besson, P. Maître Int. J. Mass Spectrom. 2011, 304, 154-164. 
[34] B. Chiavarino, M. E. Crestoni, S. Fornarini, D. Scuderi, J. Y. Salpin J. Am. Chem. Soc. 2013, $135,1445-1455$.

[35] J. Y. Salpin, L. MacAleese, F. Chirot, P. Dugourd Phys. Chem. Chem. Phys. Under press.

[36] C. C. Nelson, J. A. McCloskey J. Am. Soc. Mass Spectrom. 1994, 5, 339-349.

[37] C. X. Yao, M. L. Cuadrado-Peinado, M. Polasek, F. Turecek J. Mass Spectrom. 2005, 40, 1417-1428.

[38] C. Yao, F. Tureček, M. J. Polce, C. Wesdemiotis Int. J. Mass Spectrom. 2007, 265, 106-123.

[39] M. Qian, S. Yang, H. Wu, P. Majumdar, N. Leigh, R. Glaser J. Am. Soc. Mass Spectrom. 2007, 18, 2040-2057.

[40] A. M. Lamsabhi, M. Alcamí, O. Mó, M. Yáñez, J. Tortajada, J. Y. Salpin ChemPhysChem. 2007, 8, 181-187.

[41] O. Y. Ali, T. D. Fridgen ChemPhysChem. 2012, 13, 588-596.

[42] B. A. Cerda, C. Wesdemiotis J. Am. Chem. Soc. 1996, 118, 11884-11892.

[43] J. V. Burda, J. Sponer, J. Leszczynski, P. Hobza J. Phys. Chem. B. 1997, 101, 9670-9677.

[44] J. Sponer, J. V. Burda, J. Leszczynski, P. Hobza J. Biomol. Struct. Dyn. 1999, 17, 61-77.

[45] J. V. Burda, J. Sponer, J. Leszczynski Phys. Chem. Chem. Phys. 2001, 3, 4404-4411.

[46] N. Russo, M. Toscano, A. Grand J. Am. Chem. Soc. 2001, 123, 10272-10279.

[47] N. Russo, E. Sicilia, M. Toscano, A. Grand Int. J. Quantum Chem. 2002, 90, 903-909.

[48] N. Russo, M. Toscano, A. Grand J. Mass Spectrom. 2003, 38, 265-270.

[49] M. Noguera, J. Bertran, M. Sodupe J. Phys. Chem. A. 2004, 108, 333-341.

[50] W. L. Zhu, X. M. Luo, C. M. Puah, X. J. Tan, J. H. Shen, J. D. Gu, K. X. Chen, H. L. Jiang J. Phys. Chem. A. 2004, 108, 4008-4018.

[51] J. Poater, M. Sodupe, J. Bertran, M. Sola Mol. Phys. 2005, 103, 163-173.

[52] M. Kabelac, P. Hobza J. Phys. Chem. B. 2006, 110, 14515-14523.

[53] M.-V. Vázquez, A. Martínez J. Phys. Chem. A. 2007, 111, 9931-9939.

[54] M. Fuentes-Cabrera, B. G. Sumpter, J. E. Sponer, J. Sponer, L. Petit, J. C. Wells J. Phys. Chem. B. 2007, 111, 870-879.

[55] M. Schreiber, L. Gonzalez J. Comput. Chem. 2007, 28, 2299-2308.

[56] Z. A. Tehrani, A. Fattahi, A. Pourjavadi J. Mol. Struct. THEOCHEM. 2009, 913, 117-125.

[57] Z. A. Tehrani, A. Fattahi, A. Pourjavadi Carbohydr. Res. 2009, 344, 771-778. 
[58] S. Bagchi, D. Mandal, D. Ghosh, A. K. Das Chem. Phys. 2012, 400, 108-117.

[59] R. Kobayashi J. Phys. Chem. A. 2012, 116, 4987-4994.

[60] C. Y. Yu, Y. Yu, L. D. Gong, Z. Z. Yang Theor. Chem. Acc. 2012, 131.

[61] M. Franska Eur. J. Mass Spectrom. 2007, 13, 339-346.

[62] P. Wang, M. J. Polce, G. Ohanessian, C. Wesdermiotis J. Mass Spectrom. 2008, 43, 485-494.

[63] Z. B. Yang, M. T. Rodgers Phys. Chem. Chem. Phys. 2012, 14, 4517-4526.

[64] M. Dreyfus, O. Bensaude, G. Dodin, J. E. Dubois J. Am. Chem. Soc. 1976, 98, 6338-6349.

[65] E. D. Radchenko, G. G. Sheina, N. A. Smorygo, Y. P. Blagoi J. Mol. Struct. 1984, 116, 387396.

[66] M. Szczesniak, K. Szczepaniak, J. S. Kwiatkowski, K. Kubulat, W. B. Person J. Am. Chem. Soc. 1988, 110, 8319-8330.

[67] R. D. Brown, P. D. Godfrey, D. McNaughton, A. P. Pierlot J. Am. Chem. Soc. 1989, 111, 2308-2310.

[68] J. N. Latosinska, M. Latosinska, J. Koput J. Mol. Struct. 2003, 648, 9-18.

[69] E. Nir, M. Müller, L. I. Grace, M. S. de Vries Chem. Phys. Lett. 2002, 355, 59-64.

[70] V. Feyer, O. Plekan, R. Richter, M. Coreno, G. Vall-Ilosera, K. C. Prince, A. B. Trofimov, I. L. Zaytseva, T. E. Moskovskaya, E. V. Gromov, J. Schirmer J. Phys. Chem. A. 2009, 113, 57365742.

[71] V. Feyer, O. Plekan, R. Richter, M. Coreno, M. de Simone, K. C. Prince, A. B. Trofimov, I. L. Zaytseva, J. Schirmer J. Phys. Chem. A. 2010, 114, 10270-10276.

[72] G. Bazso, G. Tarczay, G. Fogarasi, P. G. Szalay Phys. Chem. Chem. Phys. 2011, 13, 67996807.

[73] D. A. Estrin, L. Paglieri, G. Corongiu J. Phys. Chem. 1994, 98, 5653-5660.

[74] C. Colominas, F. J. Luque, M. Orozco J. Am. Chem. Soc. 1996, 118, 6811-6821.

[75] C. Aleman Chem. Phys. 2000, 253, 13-19.

[76] J. R. Sambrano, A. R. de Souza, J. J. Queralt, J. Andres Chem. Phys. Lett. 2000, 317, 437443.

[77] R. Fazaeli, M. Monajjemi, F. Ataherian, K. Zare J. Mol. Struct. THEOCHEM. 2002, 581, 5158.

[78] G. Fogarasi, P. G. Szalay Chem. Phys. Lett. 2002, 356, 383-390.

[79] M. K. Shukla, J. Leszczynski J. Phys. Chem. A. 2002, 106, 11338-11346. 
[80] S. A. Trygubenko, T. V. Bogdan, M. Rueda, M. Orozco, F. J. Luque, J. Sponer, P. Slavicek, P. Hobza Phys. Chem. Chem. Phys. 2002, 4, 4192-4203.

[81] H. Freedman, H. N. Nguyen, T. N. Truong J. Phys. Chem. B. 2004, 108, 19043-19048.

[82] A. K. Chandra, D. Michalska, R. Wysokinsky, T. Zeegers-Huyskens J. Phys. Chem. A. 2004, 108, 9593-9600.

[83] K. Tomic, J. Tatchen, C. M. Marian J. Phys. Chem. A. 2005, 109, 8410-8418.

[84] J. K. Wolken, C. Yao, F. Turecek, M. J. Polce, C. Wesdemiotis Int. J. Mass Spectrom. 2007, $267,30-42$.

[85] G. Fogarasi Chem. Phys. 2008, 349, 204-209.

[86] D. Kosenkov, Y. Kholod, L. Gorb, O. Shishkin, D. M. Hovorun, M. Mons, J. Leszczynski J. Phys. Chem. B. 2009, 113, 6140-6150.

[87] A. Domingo, A. Rodriguez-Fortea, C. de Graaf J. Chem. Theory Comput. 2012, 8, 235-244.

[88] N. Russo, M. Toscano, A. Grand J. Phys. Chem. B. 2001, 105, 4735-4741.

[89] S. Rochut, C. Pepe, J. P. Paumard, J. C. Tabet Rapid Commun. Mass Spectrom. 2004, 18, 1686-1692.

[90] T. D. Fridgen Mass Spectrom. Rev. 2009, 28, 586-607.

[91] R. C. Dunbar, J. D. Steill, J. Oomens Phys. Chem. Chem. Phys. 2010, 12, 13383-13393.

[92] A. Lagutschenkov, R. K. Sinha, P. Maitre, O. Dopfer J. Phys. Chem. A. 2010, 114, 1105311059.

[93] D. Semrouni, O. P. Balaj, F. Calvo, C. F. Correia, C. Clavaguera, G. Ohanessian J. Am. Soc. Mass Spectrom. 2010, 21, 728-738.

[94] R. C. Dunbar, J. D. Steill, J. Oomens J. Am. Chem. Soc. 2011, 133, 1212-1215.

[95] M. Citir, C. S. Hinton, J. Oomens, J. D. Steill, P. B. Armentrout J. Phys. Chem. A. 2012, 116, $1532-1541$.

[96] O. P. Balaj, D. Semrouni, V. Steinmetz, E. Nicol, C. Clavaguera, G. Ohanessian Chem. Eur. J. 2012, 18, 4583-4592.

[97] B. Chiavarino, M. E. Crestoni, S. Fornarini, S. Taioli, I. Mancini, P. Tosi J. Chem. Phys. 2012, 137, 024307.

[98] B. Bellina, I. Compagnon, L. MacAleese, F. Chirot, J. Lemoine, P. Maitre, M. Broyer, R. Antoine, A. Kulesza, R. Mitric, V. Bonacic-Koutecky, P. Dugourd Phys. Chem. Chem. Phys. 2012, 14, 11433-11440.

[99] A. De Petris, A. Ciavardini, C. Coletti, N. Re, B. Chiavarino, M. E. Crestoni, S. Fornarini J. Phys. Chem. Lett. 2013, 4, 3631-3635. 
[100] J.-Y. Salpin, S. Guillaumont, D. Ortiz, J. Tortajada, P. Maître Inorg. Chem. 2011, 50, 77697778.

[101] Y. W. Nei, T. E. Akinyemi, C. M. Kaczan, J. D. Steill, G. Berden, J. Oomens, M. T. Rodgers Int. J. Mass Spectrom. 2011, 308, 191-202.

[102] O. Y. Ali, T. D. Fridgen Int. J. Mass Spectrom. 2011, 308, 167-174.

[103] A. A. Power, O. Y. Ali, M. B. Burt, T. D. Fridgen Int. J. Mass Spectrom. 2012, 330, 233240.

[104] B. Yang, R. R. Wu, N. C. Polfer, G. Berden, J. Oomens, M. T. Rodgers J. Am. Soc. Mass Spectrom. 2013, 24, 1523-1533.

[105] J. S. Prell, J. T. O'Brien, E. R. Williams J. Am. Soc. Mass Spectrom. 2010, 21, 800-809.

[106] J. Lemaire, P. Boissel, M. Heninger, G. Mauclaire, G. Bellec, H. Mestdagh, A. Simon, S. Le Caer, J. M. Ortega, F. Glotin, P. Maitre Phys. Rev. Lett. 2002, 89, 273002-273001.

[107] J. Oomens, B. G. Sartakov, G. Meijer, G. von Helden Int. J. Mass Spectrom. 2006, 254, 119.

[108] C. F. Correia, P. O. Balaj, D. Scuderi, P. Maitre, G. Ohanessian J. Am. Chem. Soc. 2008, 130, 3359-3370.

[109] D. Ortiz, P. Martin-Gago, A. Riera, K. Song, J.-Y. Salpin, R. Spezia Int. J. Mass Spectrom. 2013, 335, 33-44.

[110] D. Ortiz, J.-Y. Salpin, K. Song, R. Spezia Int. J. Mass Spectrom. 2014, 358, 25-35.

\section{Table and Figure Captionm}

Figure 1: a) Positive-ion electrospray mass spectrum of an equimolar $\left(10^{-4} \mathrm{M}\right)$ mixture of $\mathrm{Pb}\left(\mathrm{NO}_{3}\right)_{2}$ /cytosine $\left(\mathrm{H}_{2} \mathrm{O}\right.$ /methanol $\left.50 / 50 \mathrm{v} / \mathrm{v}\right)$ recorded at $\mathrm{DP}=20 \mathrm{~V}$, and b) low-energy CID spectrum of $[\mathrm{Pb}(\mathrm{C})-\mathrm{H}]^{+}$ions recorded with a collision energy of $30 \mathrm{eV}$ (laboratory frame).

Figure 2: Structure and B3LYP/6-311+G(3df,2p)//B3LYP/6-31(d,p)+ZPE relative energies $(\mathrm{kJ} / \mathrm{mol})$ of the lowest-energy structures obtained for $[\mathrm{Pb}(\mathrm{C})-\mathrm{H}]^{+}$complex. Bond lengths in Angströms

Figure 3: IRMPD spectrum (a) obtained for the $[\mathrm{Pb}(\mathrm{C})-\mathrm{H}]^{+}$complex compared to DFT-computed IR absorption spectra (b-d) of structures representative of different binding schemes.

Figure 4: IRMPD spectrum (a) obtained for the $[\mathrm{Pb} \text { (uracil) }-\mathrm{H}]^{+}$complex compared to DFTcomputed IR absorption spectrum of the global minimum. See Ref. [10] for details

Figure 5: Energy profiles associated with the formation of the $\left[\mathrm{PbNH}_{2}\right]^{+}$ion. Relative energies $(\mathrm{kJ}$ $\mathrm{mol}^{-1}$ ) are calculated, with respect to the global minimum (Cyt-H)-Pb7 at the B3LYP/6$311++\mathrm{G}(3 \mathrm{df}, 2 \mathrm{p}) / / \mathrm{B} 3 \mathrm{LYP} / 6-31 \mathrm{G}(\mathrm{d}, \mathrm{p})$ level of theory. 
Figure 6: Energy profiles associated with the formation of the $m / z 275$ fragment ion by elimination isocyanic acid. Relative energies $\left(\mathrm{kJ} \mathrm{mol}^{-1}\right)$ are calculated with respect to the global minimum (CytH)-Pb7 at the B3LYP/6-311++G(3df,2p)//B3LYP/6-31G(d,p) level of theory.

Figure 7: Energy profiles associated with the formation of the $[\mathrm{PbN}, \mathrm{C}, \mathrm{O}]^{+}$ion $(\mathrm{m} / \mathrm{z}, 250)$. Relative energies $\left(\mathrm{kJ} \mathrm{mol}^{-1}\right)$ are calculated with respect to the global minimum $(\mathbf{C y t}-\mathbf{H})-\mathbf{P b} 7$ at the B3LYP/6-311++G(3df,2p)//B3LYP/6-31G(d,p) level of theory.

Table 1 : Total (Hartree); zero point energy (ZPE; Hartree) thermal Corection to free energy (TCG; Hartree), and relative energies and relative free energies $\left(\mathrm{kJ} \cdot \mathrm{mol}^{-1}\right)$ of the different $[\mathrm{Pb}(\mathrm{C})-\mathrm{H}]^{+}$ structures, determined at the B3LYP/6-311++G(3df,2p)//B3LYP/6-31G(d,p) level of theory

Table 2: Experimental and computed IR vibrational bands for the $[\mathrm{Pb}(\mathrm{C})-\mathrm{H}]^{+}$complex 
Table 1 : Total (Hartree); zero point energy (ZPE; Hartree) thermal Corection to free energy (TCG; Hartree), and relative energies and relative free energies $\left(\mathrm{kJ}^{\mathrm{m}} \mathrm{mol}^{-1}\right)$ of the different $[\mathrm{Pb}(\mathrm{C})-\mathrm{H}]^{+}$ structures determined at the B3LYP/6-311++G(3df,2p)//B3LYP/6-31G(d,p) level of theory

\begin{tabular}{|c|c|c|c|c|c|}
\hline Structure & $\mathbf{E}$ & $\mathbf{Z P E}^{\mathbf{a}}$ & $\mathbf{T C G}^{\mathbf{a}}$ & $\Delta_{0} E(\mathrm{~kJ} / \mathrm{mol})^{\mathrm{b}}$ & $\Delta_{298} \mathbf{G}^{\circ}(\mathrm{kJ} / \mathrm{mol})$ \\
\hline (Cyt-H)Pb-1 & -397.6911033 & 0.087837 & 0,052739 & 83.2 & 82,7 \\
\hline (Cyt-H)Pb-2 & -397.6922534 & 0.087878 & 0.052825 & 80.3 & 79.9 \\
\hline (Cyt-H)Pb-3 & -397.6975758 & 0.088758 & 0.052528 & 68.6 & 65.2 \\
\hline (Cyt-H)Pb-4 & -397.7018146 & 0.088220 & 0.053019 & 56.1 & 55.3 \\
\hline (Cyt-H)Pb-5 & -397.6974071 & 0.088239 & 0.053258 & 67.7 & 67.5 \\
\hline (Cyt-H)Pb-6 & -397.6627527 & 0.087326 & 0.051903 & 156.4 & 154.9 \\
\hline (Cyt-H)Pb-7 & -397.7232298 & 0.088266 & 0.053363 & 0.0 & 0.0 \\
\hline (Cyt-H)Pb-8 & -397.7191119 & 0.088363 & 0.053299 & 11.1 & 10.6 \\
\hline (Cyt-H)Pb-9 & -397.7093950 & 0.087631 & 0.052434 & 34.7 & 33.9 \\
\hline (Cyt-H)Pb-10 & -397.6921698 & 0.087820 & 0.052681 & 80.4 & 79.8 \\
\hline (Cyt-H)Pb-11 & -397.6634406 & 0.087571 & 0.052378 & 155.2 & 154.4 \\
\hline (Cyt-H)Pb-12 & -397.7070670 & 0.088286 & 0.053387 & 42.5 & 42.5 \\
\hline (Cyt-H)Pb-13 & -397.6649660 & 0.087580 & 0.052339 & 151.2 & 150.3 \\
\hline (Cyt-H)Pb-14 & -397.6583754 & 0.087107 & 0.051647 & 167.3 & 165.8 \\
\hline (Cyt-H)Pb-15 & -397.6376911 & 0.086413 & 0.05147 & 219.8 & 219.6 \\
\hline (Cyt-H)Pb-16 & -397.6269313 & 0.086293 & 0.050769 & 247.8 & 246.0 \\
\hline (Cyt-H)Pb-17 & -397.645979 & 0.086594 & 0.050722 & 198.5 & 195.9 \\
\hline (Cyt-H)Pb-18 & -397.629055 & 0.087001 & 0.053363 & 244.0 & 242.6 \\
\hline (Cyt-H)Pb-19 & -397.623461 & 0.086875 & 0.051573 & 258.4 & 256.8 \\
\hline (Cyt-H)Pb-20 & -397.639076 & 0.086613 & 0.051307 & 216.7 & 215.5 \\
\hline
\end{tabular}

a ) calculated at the B3LYP/6-31G(d,p) level

b) Estimated by using a scaling factor of 0.9806 for ZPE values. 
Table 2: Experimental and computed IR vibrational bands for the $[\mathrm{Pb}(\mathrm{C})-\mathrm{H}]^{+}$complex

\begin{tabular}{|c|c|c|c|c|c|}
\hline \multicolumn{2}{|c|}{ Wavenumbers } & \multicolumn{3}{|c|}{ DFT-computed intensities $(\mathrm{km} / \mathrm{mol})$} & \multirow[t]{2}{*}{ Vibrational mode } \\
\hline Exp. & Calc. $^{\text {a }}$ & $\begin{array}{c}\text { (Cyt-H)- } \\
\text { Pb7 }\end{array}$ & $\begin{array}{c}\text { (Cyt-H)- } \\
\text { Pb8 }\end{array}$ & $\begin{array}{c}\text { (Cyt-H)- } \\
\text { Pb9 }\end{array}$ & \\
\hline 1060 & 1070 & 20 & & & $\delta \mathrm{NH}_{2}$ rock. \\
\hline 1200 & 1191 & & 118 & & $\delta \mathrm{CH}+\delta \mathrm{NH}$ \\
\hline \multirow{3}{*}{$\begin{array}{c}1270- \\
1310\end{array}$} & 1273 & 130 & & & $v \mathrm{~N} 1 \mathrm{C} 2$ (ring breathing) \\
\hline & 1278 & & & 47 & $\delta \mathrm{CH}$ \\
\hline & 1321 & & & 179 & $\delta \mathrm{CH}$ \\
\hline \multirow{3}{*}{1360} & 1342 & 20 & & & $\delta \mathrm{CH}$ \\
\hline & 1373 & & 42 & & v N3C4 \\
\hline & 1378 & & & 18 & $\delta \mathrm{CH}+\delta \mathrm{NH}$ \\
\hline \multirow[t]{2}{*}{1423} & 1427 & 327 & & & $\delta \mathrm{CNH}+v \mathrm{~N} 3 \mathrm{C} 4$ \\
\hline & 1437 & & 212 & & $\delta \mathrm{NH}(\mathrm{N} 1 \mathrm{H})$ \\
\hline \multirow{5}{*}{$\begin{array}{c}1460- \\
1550\end{array}$} & 1478 & & & 125 & $v \mathrm{C} 4-\mathrm{N} 4$ \\
\hline & 1489 & 54 & & & $\delta \mathrm{CNH}+v \mathrm{C} 2 \mathrm{~N} 3$ \\
\hline & 1506 & 90 & & & $v \mathrm{C} 4 \mathrm{C} 5$ \\
\hline & 1537 & & 446 & & $4+v \mathrm{C} 4 \mathrm{C} 5$ \\
\hline & 1546 & & & 443 & $v \mathrm{~N} 3 \mathrm{C} 4+v \mathrm{C} 5 \mathrm{C} 6$ \\
\hline \multirow{5}{*}{$\begin{array}{c}1560- \\
1640\end{array}$} & 1578 & & 396 & & $v$ C5C6 \\
\hline & 1580 & & & 207 & $\delta \mathrm{NH}_{2}$ sciss $+v \mathrm{~N} 1 \mathrm{C} 2$ \\
\hline & 1605 & 123 & & & $\delta \mathrm{NH}_{2}$ sciss \\
\hline & 1619 & 1061 & & & $v$ C4-N4 \\
\hline & 1621 & & & 477 & $v \mathrm{C} 4-\mathrm{N} 4$ \\
\hline 1760 & 1773 & & 532 & & $v \mathrm{C} 2 \mathrm{O} 2$ \\
\hline
\end{tabular}

a) Scaled by a factor of 0.96 


\section{Graphical abstract}

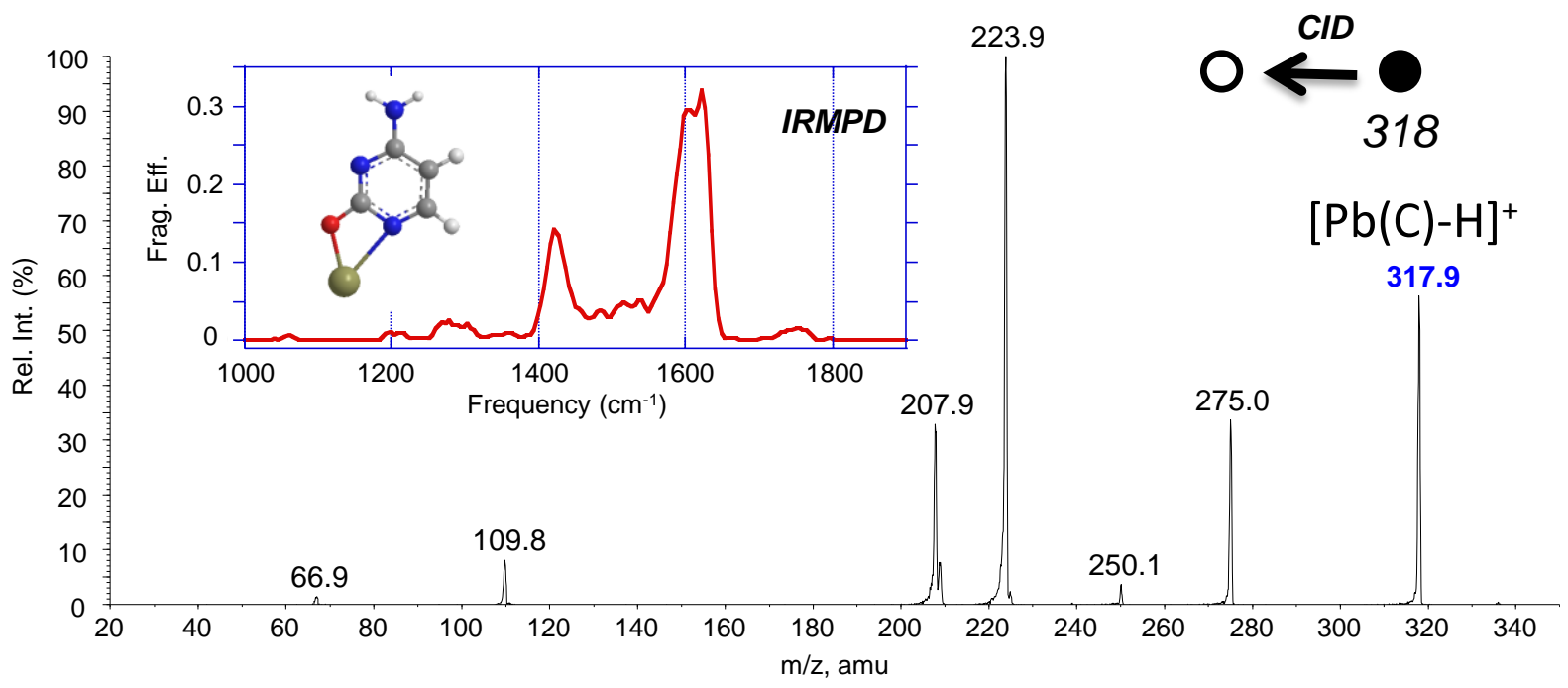

